Florida International University FIU Digital Commons

FIU Electronic Theses and Dissertations

University Graduate School

$11-3-1998$

\title{
The quincunx: a theory of yucatec maya indigenous identity
}

Juan Castillo Cocom

Florida International University

DOI: $10.25148 /$ etd.FI14060111

Follow this and additional works at: https://digitalcommons.fiu.edu/etd

Part of the Sociology Commons

\section{Recommended Citation}

Castillo Cocom, Juan, "The quincunx: a theory of yucatec maya indigenous identity" (1998). FIU Electronic Theses and Dissertations. 2079.

https://digitalcommons.fiu.edu/etd/2079

This work is brought to you for free and open access by the University Graduate School at FIU Digital Commons. It has been accepted for inclusion in FIU Electronic Theses and Dissertations by an authorized administrator of FIU Digital Commons. For more information, please contact dcc@fiu.edu. 


\section{FLORIDA INTERNATIONAL UNIVERSITY}

Miami, Florida

A thesis submitted in partial satisfaction of the

requirements for the degree of

MASTER OF ARTS

IN

COMPARATIVE SOCIOLOGY

by

Juan Castillo Cocom

1998 


\section{To: Dean Arthur W. Herriott}

College of Arts and Sciences

This thesis, written by Juan Castillo Cocom, and entitled The Quincunx: A Theory of Yucatec Maya Indigenous Identity, having been approved in respect to style and intellectual content, is referred to you for judgement.

We have read this thesis and recommend that it be approved.

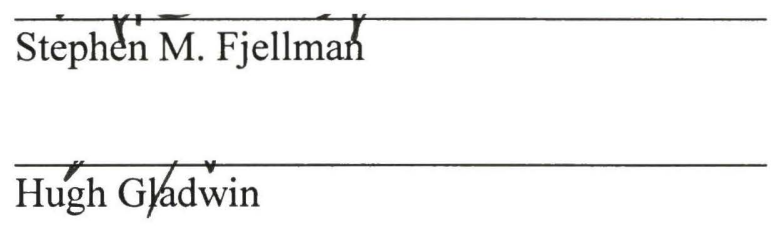

Kathleen Martín, Major Professor

Date of Defense: November 03, 1997

The thesis of Juan Castillo Cocom is approved.

Dean Arthur W. Herriott

College of Arts and Sciences

Dr. Richard L. Campbell

Dean of Graduate Studies

Florida International University, 1998 
CCOPYRIGHT 1998 by Juan Castillo Cocom

All rights reserved 
For Don Sixto and Doña Raquel,

Melba, Víctor David, Víctor, Esteban, María José, Joél, Israél, and Gloria, with thanks 


\section{ACKNOWLEDGMENTS}

I am very much indebted to Dr. Kathleen Martín, Dr. Hugh Gladwin, and Dr. Stephen Fjellman, members of my committee who encouraged me to look at the world through anthropological eyes.

For his support and guidance I am especially grateful to Dr. Mark Rosenberg, director of the Latin American and Caribbean Center (LACC) and director of the FloridaMexico Institute, an institution that granted me a full-time out-of-state tuition waiver.

I am specially indebted to Dr. Quetzil E. Castañeda for reading and criticizing the original draft of this thesis. My gratitude to Dr. Janet Chernela for her encouraging comments and suggestions. I am also grateful to Dr. Robert McKenna Brown for his support, for being my friend, and for encouraging me to study anthropology.

I want to express my gratitude to Michele Lamarre for her patience, support, and friendship. I am specially grateful to Orville Taylor for his guidance, comments, and criticisms. I am also thankful to Michael Barnett for his suggestions and ideas. My gratitude to Julie Elizabeth Clark for her support, advice, and friendship.

A special thanks to Michaela Keck for her helpful intellectual contributions to this thesis. My gratitude to Petra Purkarthofer for her confidence in me and her encouraging comments. My gratitude to Tonya Wolford for timely comments and support. I also want to thank Linda Callejas, Orlando Green, Karla Castillo, Adela Parrilla, Yomarie Silva, Hilje van der Horst, and Gary Holbrook for their ideas and patience. 
I wish to thank José Fuentes Gomez of the Facultad de Ciencias Antropológicas de la Universidad Autónoma de Yucatán for his advice and support. I also want to thank Carlos Bojórques Urzáiz for his comments and faith in this text. I am especially grateful to Juan Valencia Bellavista for his support and encouraging comments. I am very much indebted to Dr. Kathleen Martín for her support and confidence in me and allowing me the opportunity to immerse myself in the anthropological world. 


\title{
ABSTRACT OF THE THESIS
}

\section{THE QUINCUNX: A THEORY OF YUCATEC MAYA INDIGENOUS IDENTITY}

by

\author{
Juan Castillo Cocom \\ Florida International University, 1998 \\ Miami, Florida \\ Professor Kathleen Martín, Major Professor
}

A major concern in Cultural Anthropology has been the question of change and continuity. In a world immersed in a process of globalization, with concomitant socioeconomic and political effects, the quest for ethnic reaffirmation, and indigenous identity, has increasingly become reconsidered by scholars from without and from within cultures under geared change. Indigenous identity is thus the main theme of this thesis, specifically based on ancient Maya cosmovision, which is applicable to the present-day Maya. This inquiry, by means of text interpretation of the Maya sacred books, the Popol Vuh and the Books of Chilam Balam, coupled with descriptive commentary and ethnographic fieldwork carried out in Yucatán in the past three years, led to what is presented here as a theoretical model of Mayaness. This thesis discuss the essence of being Maya by interpreting current Maya reality through ancient Maya texts, and thus, reinventing that reality. 


\section{TABLE OF CONTENTS}

CHAPTER

PAGE

1. The Quincunx: a Theory of Yucatec Maya Indigenous Identity

Introduction

2. The Idea of Maya: Micro and Macro Perspectives on Maya Studies

Literature Review and Conceptual Framework ……........................................... 7

Macro Perspective on Maya Studies ...................................................................... 9

Micro Perspective on Maya Studies ................................................................... 15

3. Theoretical Concerns in the Search for Models of Mayaness

Time for Creativity/Time for Invention

4. From Text Interpretation to Theory

Breaking up the Topical and Descriptive Approach ............................................. 34

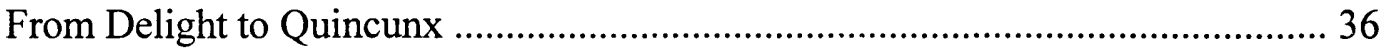

The Sacred Texts: The Popol Vuh and The Books of Chilam Balam ................... 41

5. The Quincunx

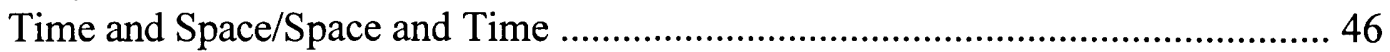

Text Exposition: The Creation ............................................................................... 48

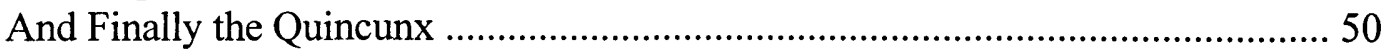

From Fieldwork to Quincunx/From Quincunx to Delight ................................... 54

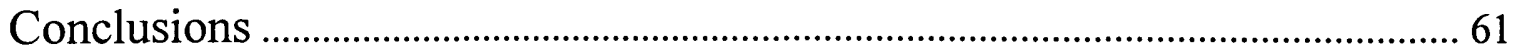

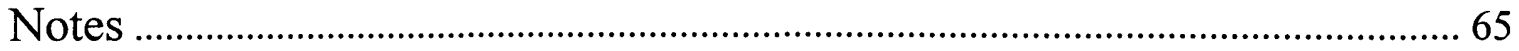

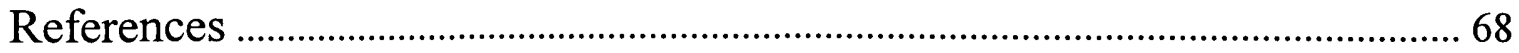




\section{LIST OF FIGURES}

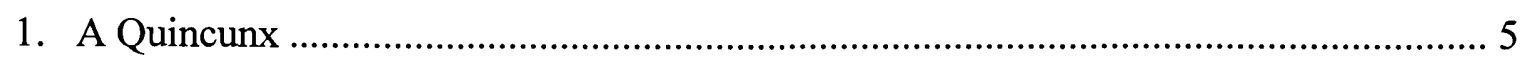

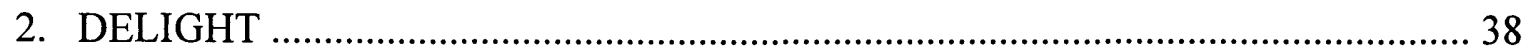

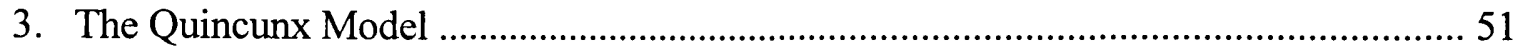




\section{LIST OF MAPS}

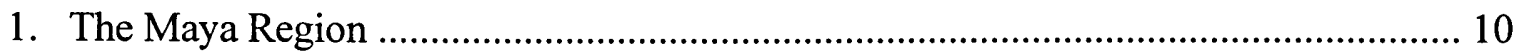

2. Regions and Economic Zones in the Yucatán State ................................................. 13

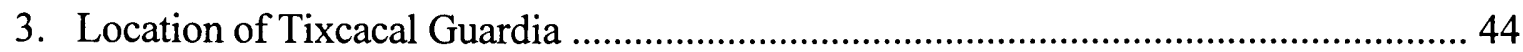


Chapter One

\section{The Quincunx: a Theory of Yucatec Maya Indigenous Identity}

\section{Introduction}

Many social scientists use the term Maya in a manner that is either generic or loosely defined. Before describing and writing about society and culture, we must insure that the terms we use are defined with carefully crafted precision. Equally, the unique perspectives and experiences of the researchers themselves, specifically as related to ethnic identity, should also be recognized or, at least, acknowledged. Ill-defined terms as applied to Maya groups or individuals, rather than enabling an understanding of the Maya as human beings, convert them into objects of study. This conversion is dehumanizing.

Thus the primary objective of this thesis is to explain the concept of Mayaness, or the essence of being Maya. Accordingly, I seek to establish a theoretical model of Mayaness through a synthesis of various social science theories which discuss Maya indigenous identity, and to make a subsequent assessment of these theories from an indigenous perspective. The synthesis of these theories is based on the notion that all social phenomena are multifactorial, multifaceted and multi-vocal (Massey and Arango 1993). Therefore, social phenomena are best explained from a variety of perspectives that broach the relevant issues from different vantage points and from different conceptualizations. The attempt to explain 
a social phenomenon, such as indigenous identity, without taking into account its multifactorialness, greatly limits the understanding of the phenomenon under study.

Another essential consideration of this paper concerns the identity of social science researchers who study the Maya. The vast majority of the studies which examine Maya indigenous identity have been undertaken by researchers who are not indigenous, and who, therefore, represent an outsider perspective. In this work, the terms "outsider" and "insider" perspectives refer to the manner in which nonmembers approach a given culture when trying to study and explain it. The advantages and disadvantages of the terms "insider" and "outsider" have been discussed by sociologists and anthropologists in terms of their ethnographical research (Golde 1970; Merton 1972; Nash 1963). An outsider perspective is said to have advantages, such as "objectivity" and scientific detachment (Kikumara 1981:139). Limitations are said to arise when the "outsider" deals with situations characterized by non-familiarity or a lack of internal insight or the native language. In contrast, an insider perspective purports to:

"...claim that group membership provides special insight into matters (otherwise obscure to others) based on one's knowledge of the language and one's intuitive sensitivity and empathy and understanding of the culture and its people." (Kikumara 1981:139)

However, there are acknowledged limitations related to such an intimate knowledge of the people and their culture, which can be taken for granted by the "informant" who may fail to completely reconstruct the whole picture. According to R. K. Merton, however, it is important to: 
"...no longer ask whether it is the Insider or the Outsider who has monopolistic or privileged access to social truth; instead, we [should] begin to consider their distinctive and interactive roles in the process of truth seeking." (1972:22)

I take Merton's stand in this thesis. The current thinking in social science is to report as accurately as possible the positioning of the researcher vis-à-vis the people with whom she or he works. The particular position taken in this paper is one of a researcher who analyzes indigenous identity from the point of view of a person who has traditionally been identified as a member of the "object" of study. I am a Maya; and while I acknowledge the contributions of non-Maya researchers (Watanabe 1997; Fischer and McKenna Brown 1996; Schele, Freidel, and Parker 1993). I will attempt to explain Mayaness on the basis of a Maya cosmovision, of Maya learning, and intellectual constructs.

The examination of Maya indigenous identity will be based on historical Maya sources, especially the Popol Vuh (Quiché Maya stories about the creation of the world) and The Books of Chilam Balam (Yucatec Maya cosmology); Maya oral tradition; personal interviews with fellow Maya; and my own experiences as a Maya and an ethnographic researcher. I will reframe these sources and at times reinterpret the Popol Vuh in order to examine Mayaness and find an explanation of Maya indigenous identity within the Maya Cosmovision.

Through an analysis and synthesis of the above sources, I would like to propose a theoretical model of Maya indigenous identity. The interpretations of the Popol Vuh and the Chilam Balam texts, coupled with descriptive and ethnographic commentary, will result in a "map" of Mayaness, or a theoretical attempt to define the term Maya. The confrontation 
of the actual model itself with the reality of the Maya, could be considered a "tour."

The terms "map" and "tour" are concepts utilized by de Certeau (1984) contributing to the theoretical/philosophical pursuit of establishing the relations and interrelations between event and structure. Maps, according to de Certeau, are more connected with space and spatial descriptions. They are also frames of reference that have their ultimate origin in everyday life, and that are critical, and an objective representation of the known (places and ethnographies are examples of maps). On these, tours are built, and they are concerned with action and interaction. Tours are subjective and intersubjective knowledge based on experience (Castañeda 1996:2). The temporary use of space within a period of time can be an example of a tour. In this work, the citations and references leading to the theoretical model will be a map. Arriving at the theoretical model will be a tour. The application of the theoretical model to Mayaness is in turn more like a tour, or a combination of these two forms of narrative.

The theoretical model stemming from this map is called the quincunx: a term developed by Evon Vogt (1990:17). It refers to a geometrical arrangement of five elements, each on one corner of the arrangement, with a fifth element in the center (see figure 1). The five elements of the quincunx each represent an essential aspect of Mayaness, with no single element more important than any other. A metadialectical relationship is maintained among the five components. The quincunx is discussed here with an emphasis on how it can, as a model, be applied to the description and discussion of the modern-day Maya and Mayaness.

There are five main currents through which Maya, Mayaness, Maya culture, Maya Cosmovision, and so forth can be explained. These five currents are history, language, tradition, religion and milpa (this term derives from the Nahuatl or Aztec word for maize 


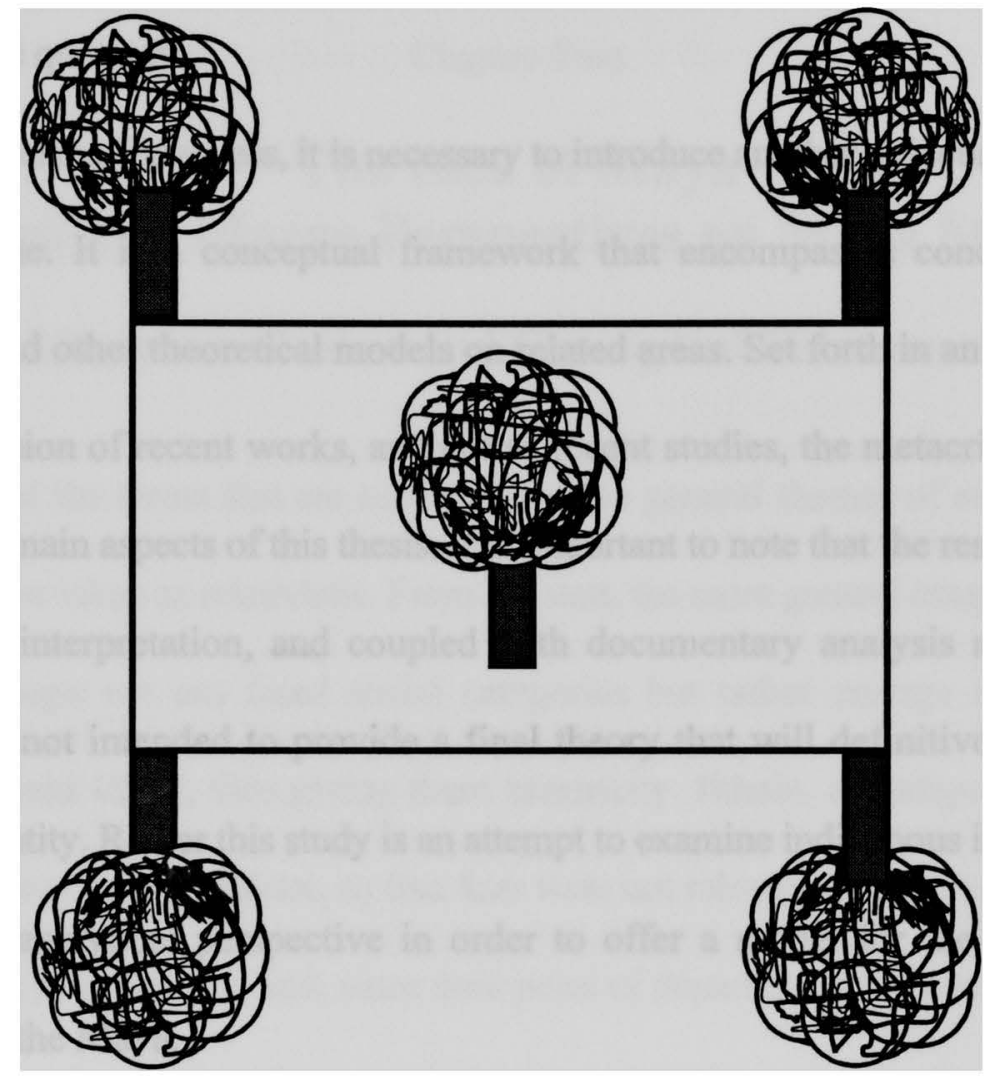

Figure 1. A Quincunx

According to the Webster's Collegiate Dictionary, a quincunx is an arrangement of 5 objects in a square or rectangle, one on each corner and one in the center. This term was originally used by Vogt (1990) in his book The Zinacantecos of Mexico. A Modern Maya Way of Life. In Zinacantan, in Highland Chiapas, the terrain formed by limestone and volcanic mountains is the Balamil, their world, conceived by them as a large quincunx of four sides at right angles, that reaches into the clouds and in the center of which is the "navel of the world"- - a low and rounded earth mound in the ceremonial center of Zinacantan - and from which the whole world extends out (1990:17). Offerings of candles, copal incense, and prayers are maintained in a nearby shrine where the Zinacantecos go while on pilgrimages to their ceremonial center. (Vogt 1990:17) 
field, milpa. The Yucatec Maya word for corn field is col. The products of the milpa are: maize, beans, squash, and chile.) Having introduced these five concepts, it is necessary to find the interrelationship among them via a correlation of existing theoretical models in order to construct the quincunx.

In discussing Mayaness, it is necessary to introduce another quincunx-a theoretical, metacritical one. It is a conceptual framework that encompasses concepts, theoretical orientations, and other theoretical models on related areas. Set forth in an exposition and a general discussion of recent works, and not so recent studies, the metacritical quincunx is relevant to the main aspects of this thesis. It is important to note that the results of this study, based on text interpretation, and coupled with documentary analysis and ethnographic fieldwork, are not intended to provide a final theory that will definitively explain Maya indigenous identity. Rather this study is an attempt to examine indigenous identity, assuming a critical and analytical perspective in order to offer a model for the interpretation of Mayaness and the Maya. 


\section{Chapter Two \\ The Idea of Maya Micro and Macro Perspectives on Maya Studies}

\section{Literature Review and Conceptual Framework}

Many of the terms that are connected to the general themes of ethnicity, or ethnic group, have to be taken as relativistic. From the start, the more general categories of ethnicity and ethnic groups are not fixed social categories but rather emerge in the context of colonialism (Field 1994), thus giving them historicity. Ethnic, or indigenous, identity are forms of resistance to colonialism, so that they were not relevant before the colonial period. In this sense they are relative, and, since their point of departure is the resistance of a native culture to foreign domination from another culture, it follows that the dominated culture is in a struggle for survival. Cultural survival, which holds on to tradition, whether authentic or reinvented, is an academic position that is concerned primarily with cultural identity.

The "cultural survival" position, which became formulated during the $1980 \mathrm{~s}$, is especially concerned with indigenous forms of resistance as they try to maintain their identity, and therefore seek out the essence of their cultural identity. The "cultural survival" position is also referred to as the "essentialist position" for that reason. It derives from Boas's historical particularism and the British functional structuralism. At the center of the school, "cultural survival" introduces a morality whereby the social scientist must see as his/her duty 
to defend the survival of indigenous cultures (Field 1994:237-241). In addition, as Fischer and McKenna Brown (1996) have noted, many Maya scholars themselves take essentialist position vis-à-vis their own culture.

One of the problems evident in Maya studies is the vague and superficial use of the term Maya itself (Re Cruz 1996; Fischer and McKenna Brown 1996; Martín and Castillo Cocom 1995; Castañeda 1996; Cojtí Cuxil 1996). Furthermore, Maya culture traditionally has been studied from a micro or a macro level of analysis, depending on who is conducting the studies. The micro level encompasses a wide range of phenomena that occur at the level of individuals and small groups. The macro level runs from positions to populations to society and its structures to world systems. Sometimes what is called macro may include micro characteristics and vice versa. That is to say these two terms are relative and therefore create mixed interpretations among anthropologists, sociologists, and other social scientists. As stated by Ritzer, even though sociologists use many terms that sound alike, at the

“...micro level (psychological characteristics, action, behavior, practices, intentional agent, micro objectivity and subjectivity, interaction, life-world, etc.) and at the macro level (structural contexts, system, population, positions, macro objectivity and subjectivity, structural properties of social systems, society, culture), and are in fact often substantial differences...Further complicating matters is...the claim that the micro-macro terms are not descriptions of empirical realities but rather are analytic concepts that can be used to analyze any empirical reality." (1992:541) 


\section{Macro Perspectives on Maya Studies}

At the macro level of analysis, the Maya have been presented in a number of ways which can be grouped accordingly: as a group which has inhabited or currently inhabits certain regions in Mesoamerica (see map 1) (Morley 1983; Thompson 1970; Villa Rojas 1987); or as a compact and homogeneous group (Breton 1994; Ligorred 1993; Morley 1983; Brito Sansores 1979). I think that these studies also emphasize the Maya as a cultural group yet this studies ignore the differences among the more than 30 distinct Maya cultural groups. It should be noted that diverse Maya groups live in Mexico, among which are the Chontal (State of Tabasco) the Chol, Lacandon, Tzeltal, Tzotzil, and Tojolabal (State of Chiapas) and the Yucatec Maya (Yucatán Peninsula). Among the Maya groups that live in the border area of Mexico and Guatemala, are the Chuj, Mam, Jalalteco and Motozintleco. In Guatemala are the Kanjobal, Ixil, Kekchi, Pocomchi, Uspanteca, Aguacateca, Quiché, Tzutujil, Cakchiquel, and the Pocoman groups. In the borderlands of Guatemala and Honduras are the Maya Chorti, and in Belize, the Itza (Diario de Yucatán 1997d).

The common feature in these aforementioned perspectives is their regard for the Maya indigenous groups as objects of study. However, these are not the only examples. Other examples of macro perspectives can be seen in works that emphasize the Maya as part of, and taking part in, ongoing processes at various levels and to different degrees. In this way, the Maya are considered, along with all the other indigenous groups of Middle America, as a product of history (Bonfil Batalla 1992, 1994; Aguirre Beltrán 1992; González y González 1989; Montalvo Ortega 1988; Barrera Rubio 1984) a subordinate group exploited by the capitalist system (Sam Colop 1996; Bartolomé 1988) a group immersed in a process 


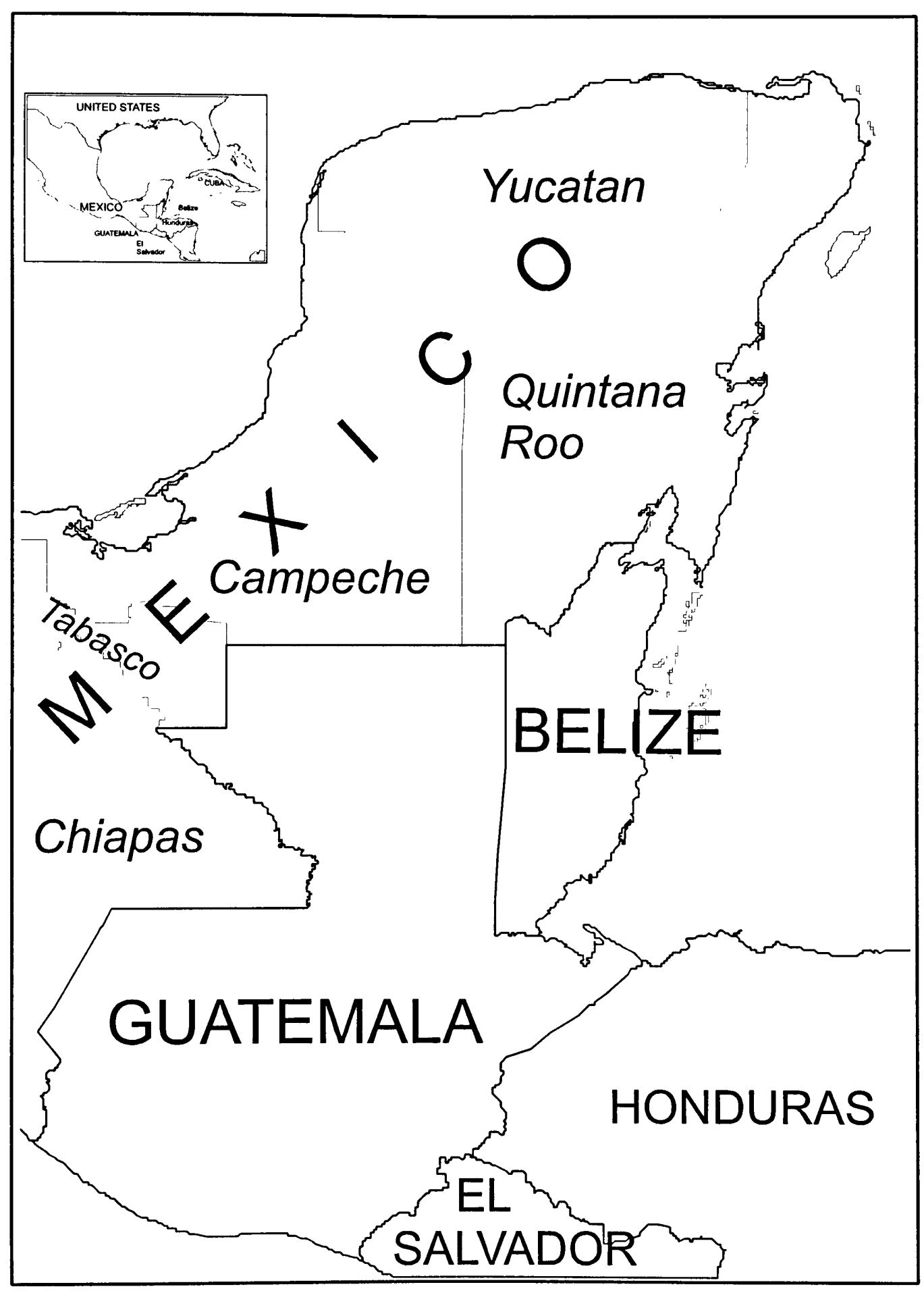

Map 1. The Maya Region

Map by Hugh Gladwin. 
of revitalization and rebirth (Fischer and McKenna Brown 1996) a mystic and exotic group (Thompson 1970; Moseley and Terry 1984) a group whose culture is in danger of disappearing as the result of the process of globalization (Ligorred 1993; Zea 1991) or as result of the encroachment of modernity (Redfield 1941).

In exploring Redfield's singular conception of indigenous groups, Henri Havre (1984) states that Redfield refuses to consider the Yucatecan and Guatemalan Maya collectivities as specific, individual cases. In doing so, Redfield not only rejects their exotic qualities, but moreover, characterizes them as social groups that he terms little, traditional, and even folk. With regard to Maya collectivity in general, it is necessary to point out that there is a diversity of Maya communities; a diversity of Maya individualities; a diversity of visions and voices; and a diversity of differences and commonalities (Schele, Freidel, and Parker 1993; Cojtí Cuxil 1991; Martín y Castillo Cocom 1995). These differences among the diverse Maya groups — and individuals—-do exist as a result of individual dynamics that stem from the distinct historical, political, and social interactions of each Maya group or individual.

Macro perspectives contribute to the understanding of Mayaness because they are oriented - and should be-to multifactorial, multifaceted, and multi-vocal cultural contexts. A concept like Mayaness can be seen from macro perspectives as more the sum of its parts than as a result of rebuilding the whole from one of the parts. Other approaches that fit into macro perspectives are multi-disciplinary and seek to enhance the probability of getting closer to the realities behind concepts-an approach that might be considered a form of positivism. But macro perspectives, precisely because of their complex nature, are subject to much scrutiny, often due to partial and one-sided views, imbalance in the quantity and 
quality of the information, vagueness in terminology, and contradictory theoretical elements existing within a model.

Concerning the idea of Mayaness, it is important to remember, for example, that it is not the same to speak of the Maya of Mexico and the Maya of Guatemala, much in the same way that the Maya from Chiapas are a distinct group from the Maya of the Yucatán Peninsula. Even within the Yucatán State differences could be found among the Maya, for example, from the five zones of production (see map 2): 1. henequen (An agavaceae plant,. its fiber is excellent for making cordage.), 2. cattle raising, 3. coastal fishing, 4. corngrowing, and 5. the citrus production zone ${ }^{1}$ (Cardiel Coronel 1989; Martín and Castillo Cocom 1997; Re Cruz 1997; Villanueva Mukul 1993; Montalvo Ortega 1988; Paoli 1984). Each group is differentiated from the others due to specific dynamics and contradictions which have resulted from different socioeconomic and historical processes shaped by local, regional, national, and international factors.

Accordingly, it is difficult for macro-focused studies not to generalize and strive to "discover" new social realities. Contemporary Maya groups are the result of their own social, historical, and linguistic project, therefore, different from cultural projects. The internal/external contradictions of the different indigenous Maya groups are the result of their own contextual differences, which exist within their own cultural group.

When talking about these differences among the Maya, I can refer to those that were perceived as being Maya, and most confidently and from interviews with those individuals who self-ascribe as Maya. From an individual standpoint, to say "I am a Maya," which means to me that I am self-ascribing to that indigenous group willingly and knowingly. To a certain extent it is irrelevant to me if "that" indigenous group exists "for real" or is an invention. 


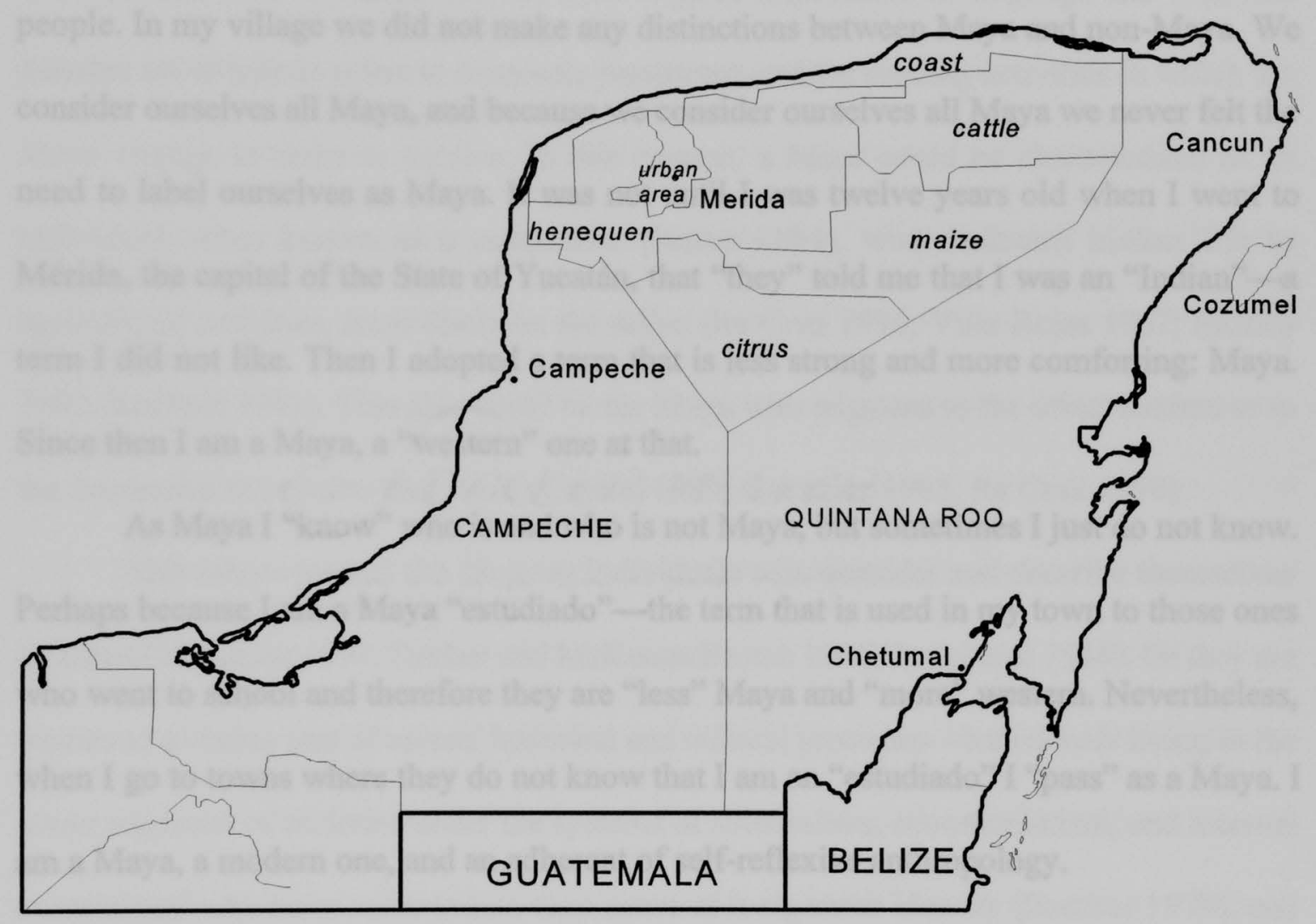

Map 2. Regions and Economic Zones in the Yucatán State Map by Hugh Gladwin. 
Nonetheless, something is for sure: I am a Maya. This does not mean that I do not consider myself as "western" as well, because I am western. Being "western" anyway is more illusory than reality, because the Yucatecan society "recognizes" me as a non-western person, a nonMaya, but as an Indian - with all the negative connotations that the term implies.

I grew up in Xocenpich, Yucatán, a town in which there were no "Mayas," but only people. In my village we did not make any distinctions between Maya and non-Maya. We consider ourselves all Maya, and because we consider ourselves all Maya we never felt the need to label ourselves as Maya. It was not until I was twelve years old when I went to Mérida, the capital of the State of Yucatán, that "they" told me that I was an "Indian"-a term I did not like. Then I adopted a term that is less strong and more comforting: Maya. Since then I am a Maya, a "western" one at that.

As Maya I "know" who is and who is not Maya, but sometimes I just do not know. Perhaps because I am a Maya "estudiado"--the term that is used in my town to those ones who went to school and therefore they are "less" Maya and "more" western. Nevertheless, when I go to towns where they do not know that I am an "estudiado" I "pass" as a Maya. I am a Maya, a modern one, and an adherent of self-reflexive anthropology. 


\section{Micro Perspectives on Maya Studies}

From a micro perspective, a Maya, like other indigenous person, is identified as an individual who lives in a rural area, is generally monolingual, and practices ancestral traditions (Villa Rojas 1987; Gamio 1992; Vogt 1990; Bonfil Batalla 1991). Such identification follows ethnic criteria, since it gives importance to language and tradition. Another set of criteria refers to economic parameters and the ensuing activities in which the Maya engage in order to survive. In this context, a Maya could be characterized as an individual, often known as a campesino (Havre 1984), who dedicates his/her life to agricultural activities, most likely on the milpa (Re Cruz 1996; Villa Rojas 1987; Morley 1983; Redfield 1941). This also could be the Maya who migrates to the urban centers or to the haciendas in order to find work (Cardiel 1989; González 1995, Re Cruz 1996).

Still others present the Maya as individuals who consider and describe themselves as Maya (Watanabe 1997; Fischer and McKenna Brown 1996; Bartolomé 1988). Or they are perceived as being part of several historical and cultural processes--individuals living in the lower segments of societies under the systems of colonialism, neocolonialism, and internal colonialism ${ }^{2}$ who have come to lose their sense of indigenous identity (Barabas 1979), and find themselves immersed in the process of Ladinization (McKenna Brown 1996; Watanabe 1997). Ladinization can be defined operationally as the process by which an indigenous person moves away, or is forced to do so, from his/her cultural molds in order to adopt others that are foreign to them - the molds of Ladino culture (Watanabe 1997 Fischer and McKenna 1996). In the case of Guatemala and the Chiapas highlands in Mexico, many of the indigenous people become Ladinos sometimes against their will 
"...in an effort to avoid cultural discrimination and to facilitate their integration into the national education system and regional commercial networks controlled by Ladinos. Successful 'passing,' however, requires not only that Indians adopt Ladino cultural traits and identify them as Ladino, but also that others recognize them as Ladino." (Fischer and McKenna Brown 1996:11)

So far the definitions concerning the term Ladino have been, as said before, very general. In the past, there have been particular meanings attributed to it. David Frye has pointed out that among the people of Mexquitic - a village situated in the State of San Luis Potosí, Mexico-Ladino meant, during the colonial rule, "bilingual" (1996:37). Thus the term Ladinization is the loss of the cultural essence of the indigenous group, or by its individual members, willing or unwillingly, in order to assume another cultural essence.

In Yucatán, instead of Ladino, the terms used are Mestizo, Catrin, or at times, Dzul (non-indigenous peoples or people without indigenous background). These terms have many implications. ${ }^{3}$ In general terms, a difference between a mestizo and a catrin is the latter's more pronounced reliance on Spanish as an everyday language, reserving Maya language only to deal with Mestizos in the community. The Catrin, generally employed in service and commercial jobs, speak Spanish among themselves and with the Dzulob (plural of Dzul). Another difference between a Mestizo and a Catrin is their different ways of dressing. The Mestizo wears "traditional" clothes and the catrin wears western clothes. Consequently, a Maya woman "...dressed with the traditional huipil is mostly referred to as a mestiza" $(\operatorname{Re}$ Cruz 1996:179). Nevertheless, wearing a "hipil" does not necessarily mean that someone is a Mestizo. There are many women who are non-Maya and wear "hipils" at home, at parties, and for certain festivals (Logan 1995). 
Another trend of views of the Maya, deals with their ability to assimilate, resist, or adapt to the effects of acculturation (Barabas 1979; Burns 1996, 1983; Bonfil 1994, 1992; Farriss 1994; Favre 1994; Fischer and McKenna Brown 1996; Martín and Castillo Cocom 1997, 1996a, 1996b, 1995). Here, a Maya is presented as one who finds herself/himself faced with the threat of cultural extinction (Gamio 1992: 171-173; Aguirre Beltrán 1992:155-163; Bartolomé 1988: 85-87, 257-260). Similarly, another case may be when the Maya, like other indigenous people, are perceived as struggling to preserve their cultural tradition as well as their material rights, even within the context of opposing national politics (Van Cott 1994; Barabas 1996:2-6; Fischer and McKenna Brown 1996:13-16). Still, in other works, the Maya are depicted as people who are followers of a syncretic religion (Schele, Freidel, and Parker 1993:29-58; Bartolomé 1988:141-148, 180-196). In other contexts, Maya is someone who is identified as such by the larger society ( Fischer and McKenna Brown 1996:19-28; Re Cruz 1996:5-6, 156, 161).

Despite the micro/macro dichotomy characterized by the authors mentioned above, neither the micro nor the macro perspective is by itself adequate in discussing the phenomenon of indigenous identity. There is a dialectic between the two sets of realities-the micro and macro. Attempting to study Maya culture and trying to explain Maya indigenous identity without taking into account its multi-factorialness or the dialectical interplay between the micro and macro greatly limits the understanding of indigenous identity. Therefore, social constructs such as indigenous identity are best explained from a variety of perspectives that broach the pertinent issues from different vantage points and from different conceptualizations. In the next chapter I will discuss a conceptual framework for Yucatecan Maya indigenous identity. 
Chapter Three

\section{Theoretical Concerns in the Search for Models of Mayaness}

\section{Time for Creativity/Time for Invention}

Within Mexico studies, seeking to define who are Maya is of significant interest to social scientists, as is the question of who conducts such research and why. Often authors focus on a specific aspect of Maya culture, and based upon their results attempt to explain, or hint at an explanation, for the concept of Mayaness. These works are characterized by a singular perspective and suggest an all-embracing, absolute definition. Since no single perspective excludes the others, perhaps the term Mayaness could best be explained by taking or combining the major elements from the many constructs of Mayaness. Such an analysis could only be advantageous, as all social phenomena are multifaceted and multifactorial. Massey and Arango take the position that

"...rather than adopting the narrow argument of theoretical exclusivity, we adopt the broader position that causal processes...might operate on multiple levels simultaneously." (1993:455)

Nevertheless, causality is but one blessing, perhaps at the expense of other theoretical options. A theoretical model thus can be synthetic and syncretic, one which incorporates the 
useful elements from the existing theoretical models. Clifford Geertz (1991) might well side with the above. He states that the time of broad generalizations, or the quest for them, is over. Social scientists are no longer trying to equate their findings from fieldwork with the kind of validity sought in the natural, or "exact" sciences, as was done in nineteenth century Comtean positivism. Modern social sciences, for Geertz, tend to rely on the humanities in an attempt to find better tools for analyzing meaning or the significance of social life as expressed through symbols. Meaning lies at the core of interpretation of cultures while analogies and metaphors are the tools used to interpret cultural life and social conduct (Geertz 1973). Of particular interest for my thesis are three theories in particular: Game Theory, Ritual Theory, and Philology.

Game Theory, the analogy of social life as a game with definite rules and strategies that is played everyday by every one, was advanced by Neumann, Morgernstern, and, to a certain extent, Goffman. If interpreted via humanistic language, Game Theory would reflect life as a pastime. This theory might appeal to the most stubborn humanists who believe that people are essentially free, good by God's given nature, and, therefore, or in spite of this, often break the rules.

Ritual Theory is the dramatic approach to social life (Geertz 1973:262-284). In his work during the early 1970s in Bali, Indonesia, Geertz highlighted the concept that politicians incorporate ancient myths into their populist discourse in order to gain popular support. Such a strategy suggests the notion of drama in sociopolitical life. Ritual theory has applicability and acceptance as long as one is aware that acting, in real life, is not pretending. In other words, social life is not a simple scenario where humans perform: the consequences are in most instances tragic. 
Philology, according to Geertz, is a discipline centered in language, and traditionally has been concerned with the interpretation of texts-whether ancient, foreign, or even esoteric. It is the re-writing by the philologist, a kind of secondary author, and not the actual texts that in the end is considered the product of this form of analysis. In the "new Philology" the trend is to look in texts for the analogy of meaning and significance that could be applied in real, actual life. Here the quest goes in the direction of imaginative forms, whether they be popular jokes, proverbs, folkloric art, language, religion, legends, oral tradition, or myths.

According to Geertz (1991) it is time for creativity, for the invention of new theoretical models, or the restructuration of old ones: a time in which it may be valid to attempt a humanistic approach, in this case, derived from the interpretation of ancient Maya texts. Accordingly, of these three theories, Philology is most related to the purpose and scope of this thesis. With respect to the interpretation of ancient Maya texts, Bartolomé (1988:141150) points out that the sacred books (Popol Vuh, The Books of Chilam Balam, and the ancient Classic Maya Codices) were not simple records of historical happenings, events, traditions, and legends, but rather, as Mercedes de la Garza contends:

"...(those sacred texts) were the symbols of everything sacred and worthy of respect, the key to understanding space and time and to find in them, the norm of life and the principle of communitary identity..." (quoted in: Bartolomé 1988:83)

This quote is a clear case of text interpretation. Evolving from a movement that had as its center a concern for symbols, text interpretation might have started in the nineteenth century with people like Frazer and Freud. Later, in the decade of the 1930s it was rekindled 
by White (1949), emphasizing symbolism as a way of understanding culture. Therefore, it became a guide for anthropological work to view culture as a system of symbols. In the 1960s and in the 1970s this idea was recaptured and formalized into what turned out to be symbolic anthropology (Reynoso 1991:11).

In both decades the new trend was not particularly strong, and it shared intellectual space with two other fashions imported from Europe to the United States: structuralism and semiotics. The latter was more concerned with signs, than with symbols. In the second half of the 1960s, postmodernism, a movement that was to consolidate its acceptance in the following decades, emerged. The importance of postmodernism was acknowledged in recent decades, receiving general recognition in anthropology in the 1980s. Among some of the favorable circumstances that produced the intellectual climate for postmodernism are the collapse of the idealistic-materialistic debate in the early 1980s, the rise of the "writing culture school" in anthropology (Behar and Gordon 1995), the experimentation in ethnographic work, and the multiplying of theories (Reynoso 1991:26-31). Among these are the poststructuralist and postmodern theories.

Foucault and Derrida created a type of social analysis known as poststructuralism. ${ }^{5}$ Poststructuralism meant a renewed endeavor and interest in structuralist tools of analysis, leaving out the idea of social structure. Postmodernism, on the other hand, meant a complete rupture with history, as long as it continued to be identified with progress, and, more specifically, technological or scientific progress. As modern technology made "progress" become routine, there was no space for "surprises" anymore, because everything became secular and expedient. Therefore, "progress" was only a means to keep things the way they were (Reynoso 1991:16). Under these circumstances, "progress" had reached an impasse, 
and, it could be argued, so had history. If history and progress have stopped, then it is posthistory that takes their position. One of the most salient characteristics of postmodernism is its identification with post-history, and in the decades to come, its impact on anthropology would be not only this identification, but an assault on its structure (theoretical and methodological) as well (Ritzer 1992:506). As Ritzer has pointed out:

"...another key aspect of poststructuralism (and postmodernism) is its view of social totality ...Another concern of poststructuralism (shared with structuralism) is the decentering of the subject. This involves rejection of a focus on the actor, the consciousness of the actor, subjectivity, and, more generally, humanism. ...this means that we should focus on the structure of society and not the role of actors in constructing that society." (1992:506507)

Jacques Derrida (1976) promoted with the term deconstruction in the early 1970 s the virtual invalidation of any form of conceptualization, or construct. His term came to substitute the terms critic, critical, or criticism (Reynoso 1996:18-19). The feminist scholar Rosemarie Tong (1989) agrees with Derrida's general criticisms of the Symbolic Order because they are an attack on logó, phalló, and binarycentrism, its three fundamental premises. These concepts embody the primacy given to spoken word, to phallic unitary drives towards ostensibly reachable goals, and to placing everything in terms of binary oppositions, or dualism. Tong uses Derrida's general conception of deconstruction in order to critically analyze the Symbolic Order. She includes in her own critique language, spoken or written, which in this case is directed through the Symbolic Order to omit the Other: woman.

Some of Derrida's best and most well-known work is certainly his deconstruction of 
anthropological studies, in particular those carried out by Lévi-Strauss. For his deconstruction Derrida would use texts that he selected, deconstructing them in a manner parallel to applied text interpretation. His heritage is valuable precisely because deconstruction can be considered a methodological tool for postmodern anthropology. Thus, post-history, poststructuralism and postmodern anthropology have been closely related since the surging of postmodernity. And even deconstruction can be viewed, from its own perspective, as a form that is text interpretation, albeit with most likely different purposes than those of hermeneutics.

In the 1970s, according to Reynoso, an American symbolic anthropologist, Marshall Sahlins, published Culture and Practical Reason (1976), following a discussion between Jean Baudrillard and Maurice Godelier, which was a refutation by the former of the application of Marxist analysis to "primitive societies." Sahlins' text was one of the most important contributions to symbolic anthropology (Reynoso 1991:22), even if it marks an extreme point of cultural reductionism, or the pretension to explain everything in terms of culture, which is for the symbolic anthropologists a system of symbols that imposes meanings. Yet symbolic anthropology may end up becoming text interpretative and, what is more, text itself. Even if no one considers Sahlins a text interpreter, still text interpretation is an important part of his work.

In a discussion about the scientific status of anthropology, as compared to the natural sciences, Sperber (1991) points out that from the beginning of twentieth century anthropology, Radcliffe-Brown overtly overlooked the participants' version of their reality, while at the same time Evans-Pritchard was pessimistic in a way that anticipated present-day anthropology. Neither of these two positions achieved general acceptation. A third current 
of thought, one maintained by Geertz and his followers from the beginning of the 1970s is closer to Evans-Pritchard's position in that “...it takes into account not only what anthropologists do, but also what they expect to accomplish" (Sperber 1991:111).

According to Sperber, Geertz's idea of the most accurate way of understanding culture is through interpreting it. Nevertheless, Sperber holds that this is a reductionist way of discerning things. Everything is reduced to meaning, and every meaning is to be grasped through interpretation. Then, if everything could be reduced to its meaning, the outcome would be very obvious, in which case the pretension of interpretation and grasping of meaning becomes superfluous. For instance black clouds imply that it will rain (Sperber 1991:112). The irony of it is that the obvious cannot be explained, nor interpreted-another methodological loss. Sperber suggests that even though interpretations can have scientific weight, they should nevertheless be matched and reinforced by a descriptive commentary or ethnographic text.

Rappaport (1990), when describing her work among the Paez indigenous peoples of Colombia, avoids explaining the obvious, as well as explanations based on historiography. Instead, she tells how what the outsider and the Paez know about themselves is not the same. There is the question of the transposition of cultural models, or a vision from the outside. She tells of the necessity to reconsider her work more as an intellectual history of the Paez, informed ethnographically.

There is some amount of deconstruction in Rappaport's interpretation, coupled by ethnographic commentary. It is the deconstruction of Western historiography that, intentionally or not, has denied the history of those who, through history itself, became its subject matter. This kind of historiography denies indigenous groups access to their own 
history, and invents a "history" for them that is a justification of their oppression precisely by the culture that writes that historiography. As Rosemarie Tong points out:

“...the deconstructivist approach takes a critical attitude toward everything, including particular ideas or social injustices, as well as the structures upon which they are based, the language in which they are taught, and the systems in which they are safeguarded. Deconstruction is antiessentialist, not only in viewing the search for universal definitions as useless, but also in actively challenging the traditional boundaries between oppositions such as reason/emotion, beautiful/ugly, and self/other as well as between disciplines such as art, science , psychology, and biology." (1989:219)

Other binary oppositions such as the above may be: Indian/European, Indigenous/Foreign, Maya/non-Maya, and Mayaness/Otherness. In this form, another way of viewing culture interpretation may use virtually any number of variables that do not necessarily have to be binary. This is true in the case of postmodernism, where triads seem to have displaced binary conceptions, for example: ethnic identity/ knowledge/.power.

Castañeda (1996) states with regard to the above that cultural interpretation, ethnography, and dialogical anthropology, are some of the tools used in the invention or reinvention of culture. Furthermore, he states, along with Wagner, that culture is an invention by anthropologists, just as Anthropology is an invention of culture (1996:15). The very concept of Otherness is also a Western invention of Anthropology. To him Geertz's formulation that culture is an assemblage of texts, and therefore that texts are "culture," is a specific moment of great historical value and one example of the anthropologists' imagination, creativity, and invention. Castañeda's own poststructural tools, inspired by de Certeau, stem from archaeology, genealogy, following Foucault, and deconstruction, 
following Derrida (1996:10-11).

According to Tedlock (1991) analogical anthropology and analogical ethnography have been the rule since the nineteenth century in studying non-western, non-European societies. Tedlock opposes it by the recent dialogical anthropology (1991:39), where aside from being based on a recurrent, constant, and dynamic dialogue between the "informants" and the "investigator," it differs from traditional (analogical) anthropology in that the reinvention of culture is done by both sides of the dialogue (not necessarily between two people only), and not just as a mere reflection of the "object of study" from the point of view of the anthropologist's own cosmovision, and frequently presented in what seems to be an ever lasting monologue. In other words, what is being presented here is a self-reflection projected upon a collectivity, just as the collectivity projects itself upon the Self.

What Geertz refers to as culture is equivalent to what Castañeda understands as the relations between maps (associated with space, descriptions, narratives, strategies of powers and places, and functionalist ethnography), and tours (associated with displacements, action, tactics of the dynamic, momentary use of space, and dialogical ethnography) (1996:2-3). Thus cultural anthropology from Castañeda's view point is in large measure, though not totally, the conjunction of maps and tours, which comprises a guidebook (concepts borrowed from de Certeau), a form of which can be found in tourism, and is the body of ethnography.

With Castañeda's position this metaquincuncial tour is over and prepares the way to start reconstructing the quincunx of Maya indigenous identity. This opening of the road, so to speak, is multidialogical and self-reflexive. Multidialogical because there is more than one dialogue in the reconstruction together of ethnographic reality. First, there is the dialogue between indigenous and non-indigenous groups. There is also the dialogue between members 
of the same indigenous groups. In this case, since the dialogue between members of the same group is very likely to be in their own language, then perhaps it would be more appropriate to consider the text as dialogues among themselves. In this context, I include myself. There is also a dialogue between $\mathrm{Me}$ and the Others - in this case the Others are the non-indigenous and Western social scientists - and a dialogue between me, the anthropologist, and my fellow anthropologists.

Following up on the last idea of the dialogues in anthropology, and between anthropologists, for this thesis, map is the better term to describe it. A map that was created hundreds of years ago, surely with another purpose than the one pursued here, but that helped the Maya to remain Maya before they were invented, and before the invention of terms in connection to this indigenous group. It is a map of interpretative, self-reflexive, and dialogical anthropology, matched with descriptive field ethnography, and geared by text thesis and text interpretation, a model that could be used to keep inventing social realities.

Without failing to acknowledge the merit of the above mentioned ideas on the terms Maya culture, Maya groups or individuals, and Mayaness, I shall attempt to do a text interpretation, or a "map" of Mayaness, and to propose a theoretical model $l^{6}$ of Yucatec Maya indigenous identity. I would like to define Yucatec Maya identity based on a reinterpretation of the Popol Vuh and Chilam Balam texts. According to the sacred book of the Quiché Maya, the Popol Vuh, and the Yucatec Maya Books of the Chilam Balam, there were four attempts to create the world and mankind and all of them failed until the fourth version, in which humans were created out of maize. ${ }^{7}$ As number four was presented at the Creation, the same number is manifest in their cosmovision. In The Books of Chilam Balam, too, there is the vision of the Earth being created on the fourth attempt and was represented: 
"...geometrically as a rectangular plane in the center of which grew an enormous ceiba tree, which supported the skies, the heavens, together with the other four mythical trees, born from each corner of the same plane." (Montoliu Villar 1987:140)

According to an interpretation on the Creation of the world from the reading of the Maya Sacred Books by Schele, Freidel, and Parker (1993:127-129), Creation consisted first of the centering of the World by placing the stones of the cosmic Earth. The next act was raising the sky, or the cosmic house, setting its sides and corners around the center. These two acts of demarcation of the periphery were performed by the gods.

Today the same act of demarcation is recreated by the Maya shamans of Yucatán, Chiapas, Belize, and Guatemala, when they reproduce this five-part image, to sanctify space and open the doors to the "Otherworld". This concept, or five-point-plain, has been termed by modern Mayanists as "quincunx," a Latin word that is used to express their cosmovision. As Re Cruz has noted, the number five (the four directions plus the center) for the Yucatec Maya is present “...in those contexts that imply completion and order" (1996:3).

I too would like to "center" Maya Yucatec identity, as in Vogt's quincunx, and open the door to Otherness - in this case Mayaness, a conception often used in recent works on the Maya. I propose that Yucatec Maya identity is like a quincunx of five dimensions: history, language, milpa, religion, and tradition, symbolically expressed as the sacred trees of life. Each of these dimensions constitutes one factor of Mayaness, with none of the trees existing in isolation from the rest. The five trees, or dimensions, are bound tightly to each other, and any attempt to understand and explain any of them must necessarily take the other four into account, or any combination of two or more elements. For example, in order to 
understand the history of Maya rebellions it is important to understand their religion. At the same time, we can't understand religion without a knowledge of Maya traditions.

Further, in quincuncial thinking, the exact position, corners or center, where each tree should be is irrelevant, since they are versatile. For example, the milpa cannot be the center by itself, because it needs the "back-up" of the others. Moreover, the center cannot be visualized in a "western" way: one tree that is supporting the whole world. The one in the center plus the four other trees, collectively, are essentially the same in Maya cosmovision. They stand in a dialectical relationship to each other, and are thus part of a dynamic system.

The form of the quincunx, as well as that of all the components and the detailed description of it, may be regarded as a map devised from outside of the Maya culture. My own conception of the theoretical quincunx is a map from the outsider perspective. On the other hand, the elements of the quincunx as interpreted from the sacred Maya texts and the reinvention of Mayaness from the metacritical quincunx, reflect an insider perspective.

My insider/outsider interpretation of Mayaness is the "journey" to the metacritical quincunx — departing from my personal experience as Maya. This “journey," for example, contributes to the comprehension of the milpa and its relationship to history and tradition. Similarly the "journey" originating from the metacritical quincunx - fieldwork, ethnographic commentary, text interpretation, dialogical anthropology, and its synthesis-encourages an understanding of Mayaness. The interrelationship among the components of the quincunx, as well as their structure and functioning measured through the actions of the Maya, are the criteria through which the quincunx can be considered more as a tour. Hence, a quincunx as interpreted from the Popol Vuh, has centripetal and centrifugal forces, because of the versatility of the five trees and the relation between the four corners and the center. While 
none of the trees is determined by the others, they each interact with the others in certain ways (Fjellman, personal communication).

This process of multiple dialectical process-all occurring at the same time-is what Fjellman calls: "metadialectical relation" (Fjellman, personal communication). Usually, dialectics, in the Hegelian sense, is understood as a dialogue between pairs, generally in opposition (Harris 1968), although not absolutely so. Binary oppositions, or the way in which the human mind is thought to operate, appear in the descriptions of cosmovisions in LéviStrauss work (1949), or in Tong's assessment of the patriarchal "symbolic order" (Tong 1989:222).

In the poststructuralist conception of how humans envision reality, there is a third element in the dialogs that centers on "triads" (Castañeda, personal communication) in constant dialogue, although not in a three-way opposition, for example, ethnic identitypower-knowledge. And if the elements become even more, it is fitting to use the term metadialectics just as Fjellman gives us to understand. Metadialectics is a dialog among more than two constitutive parts, not necessarily concrete nor abstract, like milpa, religion, and tradition. None of the parts assumes or has to assume preponderancy, although it can at times. In other words, a dialogue in which there are many constitutive parts, that can be in opposition or contrary to the other parts, but that are nevertheless, formed into a system.

The fact that metadialectics is a system is crucial to the understanding and construction of the quincunx. The quincunx of Yucatec Maya identity is not static. It is set in motion by the common symbol of a snake which moves through the five trees representing the dynamism of the lived Maya reality. The dynamism is the constant re-definition of themselves that the Maya make and have been making for hundreds of years. The re- 
definition is cyclical, and hence, repetitive. However, this does not mean that the contemporary Maya, for example, are identical to those of the $16^{\text {th }}$ century. In my opinion, a cycle which begins at $\mathrm{A}$ will finish at $\mathrm{A}$ '. This does not mean that the second " $\mathrm{A}$ " is the same as the first one, but essentially it is. This is due to the fact that while moving through space and time, variation occurs, while the path remains the same. As stated by Tedlock,

"Mayans are always alert to the reassertion of the patterns of the past in present events, but they do not expect the past to repeat exactly. Each time the gods of the Popol Vuh attempt to make human beings they get a different result, and except for the solitaire person made of mud, each attempt has a lasting result rather than completely disappearing into the folds of cyclical time. Later, when members of the second generation of Quiche lords go on a pilgrimage that takes them into the lowlands, their journey is not described as a literal repetition of the journey of Hunahpu and Xbalanque to Xibalba, nor even as a retracing of the human founders of the ruling Quiche lineages, but is rather allowed its own character as a unique event, an event that nevertheless carries constant echoes of the past. The effect of these events, like others, is cumulative, and it is a specifically human capacity to take each of them into account separately while at the same time recognizing that they double back on one another."(1996:59-60)

In a dialogue between Dr. Martín and me we compared our conceptions of time and space: the "North American" and the "Maya." I transcribe some paragraphs:

"(Dr. Martín). Like many North Americans, history began for me this AM. I start here at the dawn of morning and think about all the future that lies before me. It seems to me like a comet hurling forward into infinity. I plan for it, this time extending into the future. I look forward to events coming months in advance. Part of the excitement about the future for me is its bright semiformlessness. I can 'play' with the possibilities it holds. I can position myself in various roles regarding the events to come.

In contrast, to me, the past is an opaque block. It's over. It's ended. I don't think about the past much-because it is the past. There is nothing I can do to alter it. The past is already formed and my place in it set. It is difficult to alter history I find. And I don't like that. 
I am usually impatient. My impatience stems from wanting to go forward into the bright possibilities I think the time ahead holds. I don't want to stay rooted here. It's like wearing shoes with cleats. They hold me rooted back by my feet while the rest of my body lunges forward. I don't think much about the past. I suppose I don't care much about it...

Consequently, I think of my work as an anthropologist mostly in the future. I map it out. I (usually) meet deadlines. I bemoan that there is not enough time ahead in the future to really plan things well. Not enough time to mull things over, to savor ideas, to let them evolve or unfold in some natural way. My problem with the future is that it arrives too soon. When the future becomes today, it becomes less interesting to me. When the future becomes yesterday, it is less interesting still. I plan carefully for the future so that it will supposedly be trouble free. When the future arrives as the present, I can enjoy it."

"(Castillo Cocom). Today and my family are my existence, my time. The milpa is the Maya clock because it dictates the tempo of life. The milpa divides time into 4 periods of 3 months each: clearing the milpa, burning and then planting it and finally harvesting the corn. The sense of our life does not lie in the past nor in the future. But now in the present.

The rituals of the milpa are to honor the gods who give to us but not to the gods so that they will give to us. The whole firmament of gods, goddesses and saints in the syncretic religion of the Maya are all of the present not of the future.

For myself, I don't care if I live tomorrow because I have already lived. It is as a friend of mine says-he has had so many experiences in his life that there isn't space in his mind to remember them all.

We Maya have a fear of talking about the future. This is not a fear of the future because the future is this moment. But, for example, to admire the corn plants and predict what a great harvest one will have is 'tomoxchi' (to place a hex) on the corn harvest and invite disaster. For this reason, we don't speak much of the future because one must use so much caution to do so.

I know campesinos who wear watches but cannot tell the time on the watch face. I ask them to tell me the time and they look at the sun. To these campesinos, a watch is an adornment or a symbol of status or modernity. They don't wear watches during the day because they might break them working in the milpa. Campesinos wear them more at night. But despite the watches, time for Maya campesinos remains marking the distinction between day and night, not hours and minutes.

I think that we as Maya are humble before time. The European and North American view of history is as a sense of oneself vested in past events. For them, history is a vehicle to make sense of their existence. In contrast, the Maya never say "my ancestors built Chichen Itza or Uxmal." We as Maya are humble in our acknowledgment of time and our placement of ourselves in time. 
For many Maya time is frozen. This is why archaeology cannot explain why Maya civilizations arose and receded. For us, the Yucatecan capital city, 'Mérida', is still 'Ti'ho'; the eastern Yucatecan city, 'Valladolid', is still 'Zaci'. Five hundred years is not a long time.

In his travels through Yucatán in the early 1800's, Stephens asked questions about the past, looking for it with people who knew nothing about that past. I think Stephens wished to project this past into the future. He was projecting an abstract past onto an abstract future while forgetting the contemporary people...

For Europeans and North Americans, the past is always better and so the future can also be made better by replicating the past. I think that is why they seem to be obsessed with making second parts to films, books, etc.

For us as Maya, if the milpa fails this year, we have to wait another year to plant it again. We think not of making a second version of the milpa but to make the same milpa again....I find it difficult to think about the future or worry about it because it is always there; always we have time. My version of time moves in a cycle; her's (Dr. Martín) moves in a straight line." (Martín and Castillo Cocom 1996a)

We (Dr. Martín and me) hold not so much opposing senses of time but rather untouching, parallel of time. To a certain extent, a cycle is just a line "bent" by time and space. The cyclical re-definition of Maya indigenous identity, the interpretation of the Popol Vuh, and the quincunx itself, epitomize the Maya cosmovision. And, within this complex cosmovision there exists a sociology of knowledge. 
Chapter Four

\section{From Text Interpretation to Theory}

\section{Breaking up the Topical and Descriptive Approach}

A theoretical model can come from many sources. It can come from the original inspiration of thinkers such as Archimedes or Newton, who made some of their contributions to science through somewhat casual circumstances. On the other hand theoretical models can also be shaped from analogy with other sciences, or from real life situations, as occurs with positivism, or poststructuralism in the social sciences. What is important about theoretical models, however, is that they should be a reflection of, and find an echo in, reality.

One trend in cultural anthropology is hermeneutics, or the interpretation of texts and their meaning. This semiotic approach was advocated by Geertz and his followers. The interpretation of ancient texts has been used since the advent of modern social sciences as an analytical tool. Hermeneutics also is used by modern historians-those engaged in dialogical anthropology, ethnographic commentary, and archaeology. In this work, however, text interpretation is a mere operational tool within a range of techniques and within an already established theoretical framework, or model. In addition I will borrow concepts, notions, and orientations from analogical anthropology, dialogical anthropology, ethnographic commentary, and even reflexivity. 
The model of the quincunx was conceived while moving from an interpretation of ancient Maya texts to a theoretical model applicable to Maya present-day reality. To move from interpretation to theory implies breaking up with the topical and descriptive approach, an outlook that is, according to Peter Bergel (1990), characteristic of the texts of the day.

Like many other theoretical models, the quincunx model has its own range and scope. The range is here the historical span between old Maya cosmology, through the Colonial syncretic religion, up until the present-day beliefs and practices of the modern Maya. The scope of the metacritical model, on the other hand, is more the way in which a non-Maya social scientist might be able to attest to the realness of the model, as it is applied to the way in which the Maya envision the world today. It marks the limitations of the model, by giving it ethnographic and historical specificity; in other words, when, where, in regard to whom, and in what circumstances can this model be expected to work, and with what possible outcomes.

In the next pages, there will be an exposition of the quincunx as it is stated in the Maya sacred texts, an interpretation of it for the purposes of construing the model, and a contrasting of it with concrete examples of Maya individuals, groups, and collectivities in the present-day reality. Thus the purpose of this chapter is not a detailed discussion of the events narrated in Popol $\mathrm{Vuh}^{8}$ and The Books Chilam Balam 9 , but to take parts from them for description and analysis and to use them as tools for construction and comparison. However, a brief description of these sacred texts is necessary at the outset. 


\section{From Delight to Quincunx}

The Dialectical Exchange Among Logical Types (DELIGHT), an approach developed by Fjellman and Gladwin (1984), is a valuable tool for the synthesis of the quincunx from the above text interpretations. DELIGHT is presented in an article titled "What Ramanujan Didn't say: Sociology and the Discourse of Order" (1984:101-119). In the discussion, two issues emerge as necessary when building a sociological theory: rigor and imagination. When discussing the discourse of order in sociology, Fjellman compares the different ways in which Durkheim and Weber approach the mapping of territories.

Durkheim was concerned with the map of society based on empirical data and with form. The key to his map of society was order. Weber, on the other hand, believed in the uniqueness possessed by individuals, in terms of their orientations towards social action. Weber seeks correlation, methodological understanding (Verstehen) and differentiation between subjective and objective, relations between religious and economic patterns, always paying attention to the particular case. In Fjellman's discussion, Weber's search for meaning in history instead of structure makes him more imaginative than rigorous, as compared to Durkheim. In short, Durkheim's maps are clear because of his structural interests; Weber's ideas, limited by his interests in constitutive meaning, are fuzzy (Fjellman 1984:107).

Beyond Durkheim and Weber, Fjellman considers Marx's combination of rigor and imagination in his meta-map of society, as cutting through "...different levels of description and explanation, theory and practice, historical structure and human action" (1984:107). According to Fjellman, by using the concept of modes of production, Marx came very close to achieving his goal. 
It is not important to discuss Marx in detail in relation to Fjellman's article, but two things should be considered: first, the fact that Marx's theory, for Fjellman, is the closest in social sciences to a meta-theory, and second, the fact that Marx's use of dialectics follows an almost geometrical logic. Marx's work is relevant to the DELIGHT model because he attempted to create a theory that encompassed all aspects of society. He sought to give his theory historical depth and explain the ways in which the parts are arranged with respect to the whole (Fjellman 1984:107-111).

Fjellman's analysis of Weber, Durkheim, and Marx in developing his DELIGHT model, provides an effective theoretical tool for assembling the quincunx. DELIGHT is a model which consists of six axes arranged on a square (see figure 2). These are the alpha, beta, delta, gamma, epsilon, and zeta axes. The first four axes are arranged at right angles, while the last two are diagonally arranged. Containing the square of the axes is a slightly larger square which has, on the top side, from left to right, the categories of inside and outside the unit of analysis. On the left side, from top to bottom, the outer square aligns the categories of the material/social and the symbolic/ideological dimensions. The interplay between some of the elements is asymmetrical. This is due to what Fjellman calls the “lurking presence of logical types" (1984:109). Logical types are names of classes of which they are not ordinarily members (1984:103).

Fjellman goes on to state briefly examples of how the axes of DELIGHT work, and I think this is relevant to my idea of the quincunx of Mayaness. The horizontal axes essentially represent the process of inclusion, the vertical axes represent membership, while the diagonal axes are dialectical. The epsilon and zeta axes, represent, by appearing diagonal, contradictions among the categories of the outer square. Because this is highly relevant to 


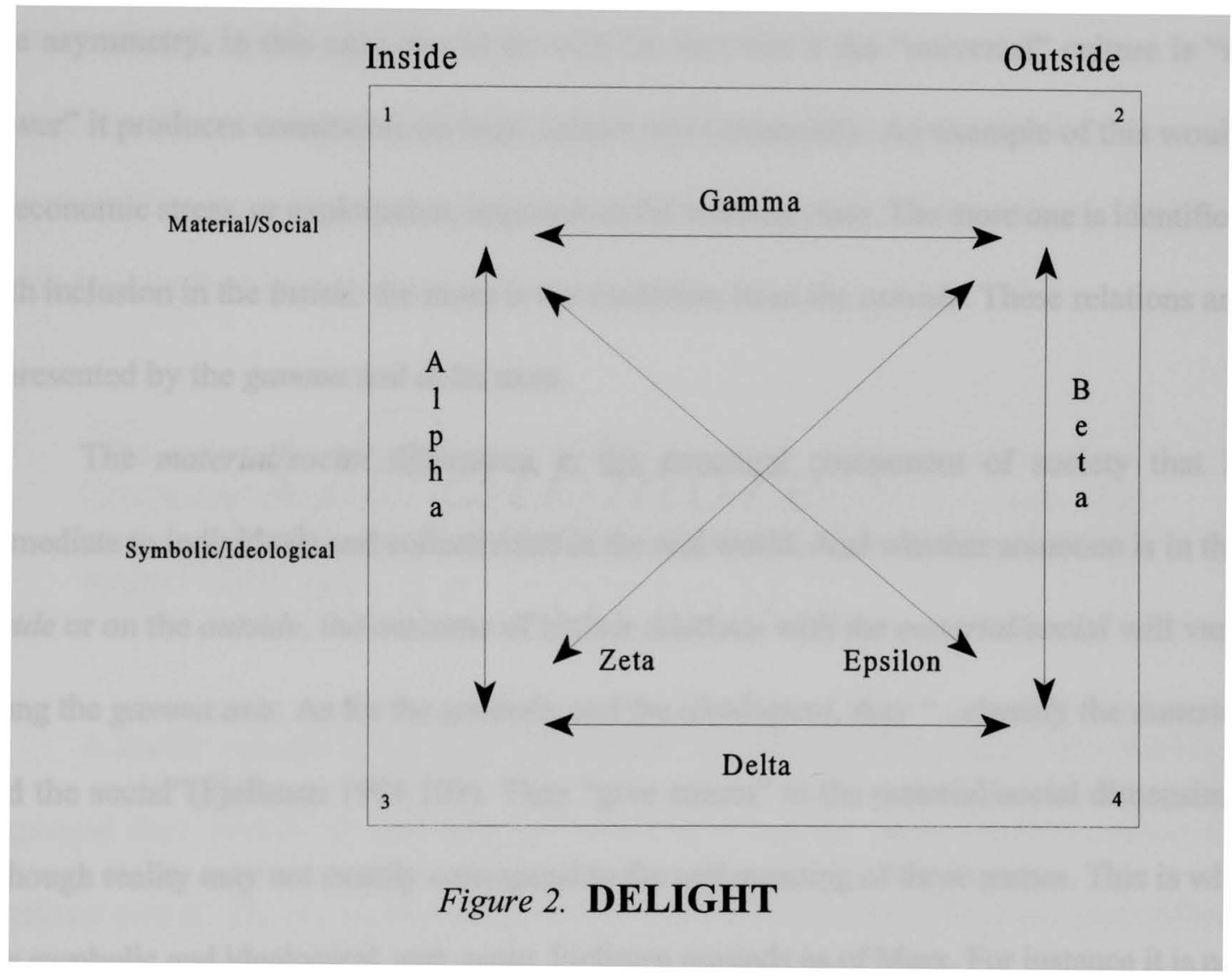

Fjellman, Stephen M. "What Ramanujan Didn't Say: Sociology and the Discourse of Order." In: Current Perspectives in Social Theory. 5 (1984): 109. Figure by Tonya Wolford 
my presentation of the quincunx, I will briefly state what these categories mean.

According to Fjellman, Inside and outside here refers to the social relations of inclusion. To be on the inside is to share a common set of ideas, values, attitudes, and roles that are closely related to smaller social groups, like the family and the community. The outside counterpart is the next larger social or material context, perhaps the larger society. The asymmetry, in this case, has to do with the fact that if the "universal" culture is "in power" it produces constraints on local culture and community. An example of this would be economic stress, or exploitation, imposed on the working class. The more one is identified with inclusion in the inside, the more is the exclusion from the outside. These relations are represented by the gamma and delta axes.

The material/social dimension is the structural component of society that is immediate to individuals and collectivities in the real world. And whether someone is in the inside or on the outside, the outcome of his/her relations with the material/social will vary along the gamma axis. As for the symbolic and the ideological, they "...classify the material and the social"(Fjellman 1984:109). They "give names" to the material/social dimension, although reality may not exactly correspond to the real meaning of those names. This is why it is symbolic and ideological, and, again, Fjellman reminds us of Marx. For instance it is not the same, symbolically or ideologically, to consider the material/social from the inside as from the outside. As the social universe grows larger, so does the ideology that names relations through symbolism. In this context the social relations are what Marx called the relations of production (1964).

Lastly, the two diagonal axes, epsilon and zeta mark the contradictions that can occur at any juncture of the categories in the outer square with the inner ones. For instance, zeta 
marks a symbolic/ideological contradiction that is projected from the inside to the outside, such as local communitary disturbances, small rebellions and other such occurrences, or we could have a projection from the outside to the inside. As its counterpart, epsilon marks a material/social contradiction that is generally projected from outside to inside.

An example of this model as it applies to the Mayan context is that of milpa. For instance when people from Chan Kom who work on the milpa, move to Cancún for work, they often refer to it as their "other milpa" (Re Cruz 1996:101), and as such represents a zeta projection from inside to outside on the DELIGHT model. The reason for this is highlighted by Re Cruz when she says,

"The successful immigrants, the urban capitalist entrepreneurs, look at Cancún metaphorically, as a fruitful, splendorous, magnificent "milpa" that rewards them with capital accumulation obtained through their business and wages." (1996:135)

A similar example is that of the millenarian ${ }^{10}$ movements of the Maya. Here the Maya employed their cosmology and religious practices to facilate their rebellions against the dominant system. The above two examples are important in that they effectively place Mayan ethnic identity in the bottom left hand corner of the DELIGHT diagram. 


\title{
The Sacred Texts The Popol Vuh and The Books of Chilam Balam
}

In the seventeenth century (1688) Friar Francisco Ximenez, Priest of Santo Tomas Chuila (currently Chichicastenango, Guatemala) managed to obtain from the Quiché Maya a book written in their language, but in Latin characters (Recinos 1960:9), and, as the Maya writer Gaspar Pedro González ${ }^{11}$ has pointed out “... with Maya ideas” (1997:2). What Friar Ximenez obtained was a copy of the original Popol Vuh text written long before the Spanish Conquest, as stated by the Quiché Maya author:

\begin{abstract}
"This we shall write thus within God's law, in Christianity; we will take it out in the light because the Popol Vuh, such was its name, can no longer be seen, where it could clearly be seen the coming of the other side of the sea, the account of our darkness, and life could clearly be seen. ...There existed the original written anciently but its view is hidden from the investigator and thinker." (Recinos 1960:21)
\end{abstract}

Tedlock has pointed out that the authors of the alphabetic Popol Vuh "...were members of three lordly lineages that had once ruled the Quiché kingdom: the Cauecs, the Greathouses, and the Lord Quichés" (1996:25). According to Schele et al (1993), the Popol Vuh, or Book of the Counsel of the Quiché, was written between 1550 and 1555 by a Quiché Maya. The Community Book of Utatlan, from which the Popol Vuh was derived, was likely a codex or set of codex books written in Maya glyphs. Edmonson (1971) notes that,

"...there are clear indications that the original also included almanac pages used for divination, comparable to the pages of the four surviving Maya Codices, three of which are probably from Yukatan and all of which date from the Postclassic period or the centuries just prior to the Spanish Conquest." (Schele, Freidel, and Parker 1993:406) 
According to Recinos, the Popol Vuh consists of three parts: one which describes the creation of the world and the origin of man; another that tells the "adventures" (a term used by Recinos) of Hunahpu and Ixbalanque in Xibalba, the underworld. The final part recounts the origin of the diverse groups that lived in pre-Hispanic Guatemala, their migrations, and their territorial distribution. It contains the names of their most important rulers, their wars, and conquests (Recinos:1960:16).

The Books of Chilam Balam were written in Yucatec Mayan during the first years of the Spanish Colonial period ${ }^{12}$. As with the Popol Vuh, some of the information might have originated in pre-Hispanic Codices (Thompson 1975; Bartolomé 1988). There are several Books of Chilam Balam that take the names of the towns where they were found. Among the texts that are most known are the Chilam Balam of Maní, Tizimin, Chumayel, Ixil, Kaua, and Tusik. The Books of Chilam Balam of Maní, Tizimin, and Chumayel, form a group identified as the Matichu, and "...they contain very revealing data about history, religion, customs of the Maya people" (Brito Sansores 1979:328).

The Chilam Balam of Chumayel was compiled in 1782, by the Chilam Balam Don José María Hoil, whose signature appears at the bottom of the book. The Chilam Balam of the Nah, was signed in 1863, by the brothers José Secundino Nah and José María Nah. The names of the authors of the other Books of Chilam Balam remain unknown. However, they were written by Maya priests, known also as Chilam Balam (Brito Sansores 1979:326).

Barrera Vasquez translates the term Chilam as "The One Who is Mouth." The term Balam, which can also be translated as jaguar, can be broken down etymologically into $\mathrm{Bal}$ (the action of concealing or hiding) and $\mathrm{Am}$ (actor). Hence Balam refers to the person who hides or conceals something. Therefore, Chilam Balam can be translated as "He Who is 
Mouth of the Occult" (1972:15). Tedlock translates the same term as "Jaguar Translator" $(1996: 25)$.

In general terms, these texts contain references to the cosmological, prophetic, and ritual orders. Further, they contain historical chronicles framed in the Maya Calendar, which relate to events that took place before, during, and after the Spanish Conquest. These historical chronicles make reference not solely to the pre-Hispanic and colonial epochs, but also include the period known as independent Mexico (Barrera Vasquez 1972; Brito Sansores 1979:323).

Contrary to what one might think, there is actual evidence that there has been continued writing of these books up to the present day. For example, Nikolai Grube has pointed out that in Tixcacal Guardia these sacred texts “....are still being used, written and read publicly by the scribes of the Cruzob" (Nikolai Grube in: Schele, Freidel and Parker 1993:167).

Tixcacal Guardia is located in the Mexican State of Quintana Roo (see map 3). It is considered the religious and political epicenter of the Cruzob people. The term Cruzob derives from a Maya-Christian cult of a Speaking Cross. They acquired the “...name of Cruzob Maya from the Santa Cruz or Holy Cross they worshiped." (Farriss 1984:19). This Christian symbol, reinterpreted through Maya cosmology, and within their religious practices, bred and organized political strategies that promoted their struggles for liberation. The Cruzob fought against the descendants of the Conquistadores in the Caste War. This war began in 1847 and ended in 1901 . However, as indicated by Bartolomé, certain military skirmishes were evidenced until 1915. Consequently, it is not until 1937 that the so-called 'Maya rebels' were “pacified” (Bartolomé 1988:179). 


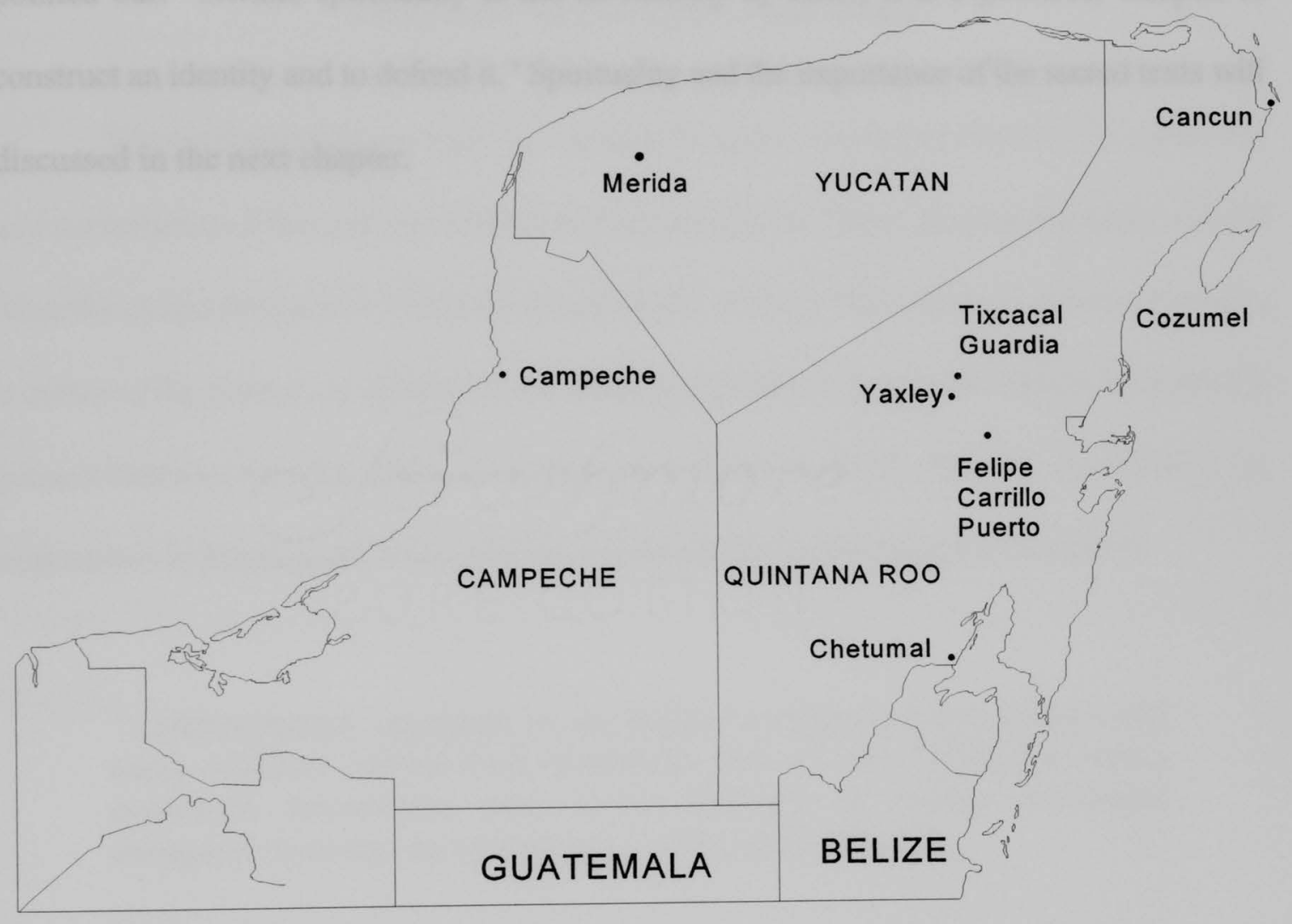

Map 3. Location of Tixcacal Guardia

Map by Hugh Gladwin 
Continuity and permanence of oral and written tradition, like in Tixcacal Guardia, constitutes one of the ways in which Maya indigenous identity is assumed by them and for them. Similarly, the symbol of the cross lie at the core of Maya indigenous identity; it constitutes a manifestation of Maya spirituality. As Logan and Castillo Cocom (1996) have pointed out: "...while spirituality is not an identity by itself, it is a powerful weapon to construct an identity and to defend it." Spirituality and the importance of the sacred texts will discussed in the next chapter. 
Chapter Five

\section{The Quincunx}

\section{Time and Space/Space and Time}

What is happening currently in Tixcacal Guardia constitutes evidence of continuity and permanence of the oral and written tradition among the Maya. In a certain sense, viewed from the cyclic perspective of history characteristic of many Maya groups, the past becomes a mirror of the present, as opposed to the linear perspective of pragmatic history in which the present becomes the time mirror of the past. M. I. Finley, in Myth, Memory, and History (as expounded in Rappaport), states that the European linear conception of history is:

"...chronological, organized on the basis of a coherent dating scheme and using evidence derived from documents that are then formulated into a systematic formulation; myth is the antithesis of history: non-linear, atemporal, fictional, non-systematic." (Rappaport 1990:12)

Cyclic history, on the other hand, as seen by the Paez with whom Rappaport worked —and whose conception of history is parallel to that of the Maya - differs from linear history in that, from the beginning, there is no emphasis on written sources. In fact it could be said that cyclic history opposes linear history, in that it relies on myths, whereas linear history relies on written documents. The latter strives for chronological accuracy, the former for meaning. Meaning in this context becomes the mirror of the past. As Rappaport points out: 
"The past is only useful insofar as it sheds meaning on the problems of the present. The Paez do not simply reflect on events of the past, they inquire into the relationships between past events and their manifestations in the present." (1990:179)

The conception of cyclic history, among the Maya, is manifested on the fact that the sacred texts are still read to the public on special occasions-with the holy crosses now being placed in the sanctuary of the church of Tixcacal Guardia, which is kept zealously protected by armed guards. According to Bartolomé, in the past the sacred texts "....were read publicly on special occasions and were jealously guarded from the reach of the Conquistadores" (1988:207). Today, as in the past, these sacred texts are fervently guarded not only by the Chilam Balam, but also by the collectivity, and the collective memory as well. And it is precisely there, in the collective memory, where the past becomes the mirror of the present. The preceding is in agreement with Grube when he states that the sacred texts of Tixcacal Guardia:

"...are the descendants of the Books of Chilam Balam. They are still being written by scribes literate in Yukatek, who keep track of the modern history of their villages and the larger world. As with the Chilam Balams, history becomes prophecy - some of which predicts the end of the world at the coming turn of the millennium." (Schele, Freidel, and Parker 1993:439)

In this fashion, the sacred texts form part of the collective memory of the Maya, that is, their own history and their own manner of understanding it in relation to their future. The collective memory is understood as the totality of time and space and not as a fragment of the temporal and the spatial. Continuity and permanence of oral and written tradition among 
the Maya constitutes one of the ways in which Maya indigenous identity is assumed by them and for them.

\section{Text Exposition: The Creation}

Gaspar Pedro González points out that both in the Maya sacred books ${ }^{13}$ and oral tradition as well, as in their everyday life, the unrelenting quest "...of the infinite, the transcendental, and the divine..." (1997:1), is manifested through time and space. These were conceptualizations that the Maya utilized in order to explain the creation of the world and the origin of mankind. This creation and origin were attributed in the Popol Vuh and in oral history to the deities of The Heart of the Sky and Hearth of the Earth ${ }^{14}$ (González 1991). According to the Popol Vuh, Creation occurred as so:

"This is the account, here it is:

Now it still ripples, now it still murmurs, ripples, it still sighs, still hums, and it is empty under the sky.

Here follow the first words, the first eloquence:

There is not yet one person, one animal, bird, fish, crab, tree, rock, hollow, canyon, meadow, forest. Only the sky alone is there; the face of the earth is not clear. Only the sea alone is pooled under all the sky; there is nothing whatever gathered together. It is at rest; not a single thing stirs. It is held back; kept at rest under the sky.

Whatever might be is simply not there: only the pooled water, only the calm sea, only it alone is pooled.

Whatever might be is simply not there: only murmurs, ripples, in the dark, in the night. Only the Maker, Modeler alone, Sovereign Plumed Serpent, the Bearers, Begetters are in the water, a glittering light. They are there, they are enclosed in quetzal feathers, in blue-green...

So there were three of them, as Hearth of Sky, who came to the Sovereign Plumed Serpent. when the dawn of life was conceived:

"How should sowing be, and the dawning? Who is to be the provider, nurturer?" 
"Let it be this way, think about it: this water should be removed, emptied out for the formation of the earth's own plate and platform, then should come the sowing, the dawning of the sky-earth. But there will be no high days and no bright praise for our work, our design, until the rise of the human work, the human design," they said.

And then the earth arose because of them; it was simply their word that brought it forth. For the forming of the earth, they said "Earth." It arose suddenly, just like a cloud, like a mist, now forming, unfolding. Then the mountains were separated from the water, all at once the great mountains came forth. By their genius alone, by their cutting edge alone they carried out the conception of the mountain-plain, whose face grew instant groves of cypress and pine...

And the earth was formed first, the mountain plain." (Tedlock 1996:64-66)

It becomes apparent, then, from this last paragraph, that in the creation in the Popol Vuh, the Earth had the form of a plain, a "mountain-plain", and on top of which grew trees. Even though, at this point, the idea of the quincunx, as presented in chapter I of this thesis, does not appear as complete and precise in its structure, we have at least two elements of that conception: Earth being a plain, and trees on top of it, the manner in which the earthly part of the cosmos is conceived. This conception of the cosmos is manifested in daily Maya life. For example, in Chan Kom, as Re Cruz has pointed out:

"The milpa cycle in Maya conceptions begins with the measuring of the square land: this is the same imagery which begins the Quiché Popol Vuh, when the first grandparents measure out the four corners of a milpa. In addition, the oral tradition in many Maya Yucatec villages pinpoints the existence of a box which is said to contain the center of the world; the box often contains a measuring twine for marking off milpa." (1996:14) 


\section{And Finally the Quincunx}

In the following paragraphs we will examine how the quincunx, outlined above, corresponds to the DELIGHT map. Figure 3 is the quincunx model, which is represented with the milpa in the center, flanked, clockwise, by history, language, religion, and tradition. In this quincunx model, if taken as static, the milpa would mean the essence of Mayaness: the milpa is an important element of tradition; it lies at the core of Maya religion; it is also an essential element of language; and it is certainly part of Maya history. Nevertheless, the milpa by itself cannot be the center since the quincunx is not a model about the milpa, but a model of Mayaness. This idea of non-exclusivity of any of the trees in the quincunx appears in the Zinacanteco universe, in which:

"... the quincuncial world rests on the shoulders of the Vashak-Men, the local version of the 'Four-Corner Gods' or 'Sky-Bearers' who played an important role among the ancient Maya." (Vogt 1990:17)

In this version, none of the "Sky-Bearers" supports a heavier worldly burden than the others. Sometimes they shift the weight from one shoulder to another (in which case an earthquake results), and other times one of them gets tired and the resulting imbalance results in more earthquakes that kill and therefore restore the equilibrium. The main idea is that all four of them are important. If one of the Sky-Bearers weakens, the other three will support the Sky, but it does not mean that the weakened Sky-Bearer will not do anything. He will do less until equilibrium is restored.

Nevertheless, it could be argued from the point of view of the theory of modes of 


\section{HISTORY $\quad>$ LANGUAGE}
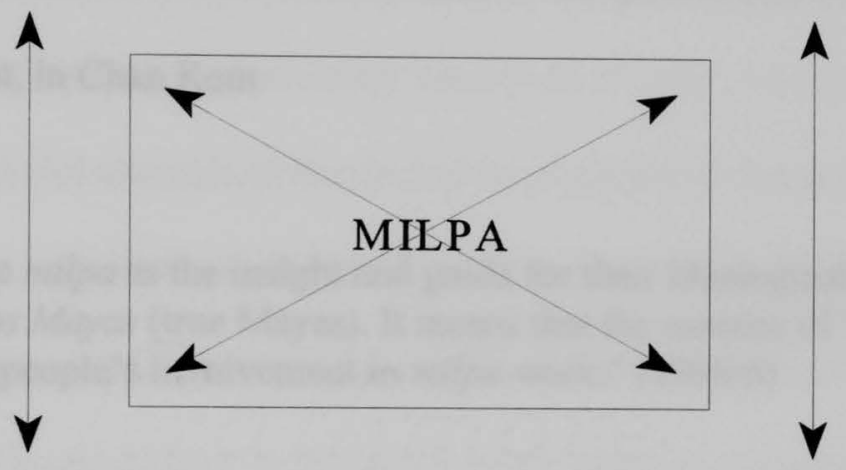

TRADITION

\section{RELIGION}

\section{Figure 3. The Quincunx Model}

In this diagram, milpa occupies the center, however, the concept of quincunx involves all possible permutations among the five elements. For example, the milpa cannot be the center by itself because it needs the backup of the others. Moreover, the center cannot be visualized in a "western" way, meaning that one tree only is the center that is supporting the whole world: the one in the center plus the four other trees, collectively, are essentially the same in Maya cosmovision. They stand in a dialectical relationship to each other and are thus part of a dynamic system. Figure by Tonya Wolford. 
production that milpa has historical specificity in an agrarian society based on the production of maize. The milpa was the system of production that conformed the material aspect of a mode of production, along with the relations of production. The products of the milpa were destined for domestic consumption, for a ceremonial fund, and also for tribute, in a system that has been correlated with the Asiatic Mode of Production (Marx 1964; Godelier 1972, 1980; Bartra 1974; Barrera Rubio 1984; Bojórquez Urzáiz 1984). The milpa was, and still is, metaphorically, at the root of the contradiction in the epsilon axis of DELIGHT. As Re Cruz has pointed out, in Chan Kom

"...people use milpa as the insight and guide for their ideological legitimacy as verdaderos Mayas (true Mayas). It means that the essence of 'Mayaness' comes from people's involvement in milpa work." (1996:6)

But the quincunx is dynamic. If any of the four other elements were in the center, there would still be a coherent interplay among them. An analogy that could be used is the modern game of Rubik's cube, although the motions would be occurring mostly on the top side of the cube, and instead of one person playing it would be an entire ethnic group, placing their identity alternatively, partially or totally, on any combination of trees and center.

Like in the Rubik's cube, milpa, tradition, history, language, and religion, are smaller cubes, or squares if seen from above that can slide into different positions. Their relative importance, as with the cube, lies in the fact that they form part of a coherent system. But this is only an analogy. In reality, the quincunx is less complicated in terms of probabilistic occurrences than the cube. The cube has a total of permutations from the twenty-five squares on each of the sides, compared to the total number of permutations of the five quincuncial 
elements. On the other hand, the quincunx can be more complicated because it deals with people, and the elements of time and space. Nevertheless, the idea for a theoretical model of the quincunx is derived, not from Rubick's cube, which is merely an analogy of how it works, but rather from an idea suggested from the Popol Vuh. Neither is the theoretical model of the quincunx intended to explain Mayaness solely on the basis of the interpretations of the Popol Vuh, and The Books of Chilam Balam.

Mayaness adjusts to the quincunx, although it does not necessarily mean that all the elements should be arranged in a given order. Moreover, it is not even necessary that all the elements are present. An example of the quincunx as applied to indigenous identity could include Maya who: 1. speak Maya and follow the traditions, 2. those who don't speak Maya but follow the traditions, 3. others who don't speak the language or practice the traditions, but still consider themselves Maya, 4. others who don't speak the language, don't follow the traditions and don't consider themselves Maya, while they are considered as such by the larger society, and 5. still there are those who speak the language, practice the traditions, consider themselves Maya, and are considered as such by the larger society. Here, we can see a synthesis of the micro/macro integration in the quincunx model.

The most abstract of all the elements of the quincunx is history, since it is formed by looking backwards. Within history is the notion of change, and Maya culture has undergone changes in all of the other elements of the quincunx: tradition, religion, language, and even in the milpa. With respect to traditions, some have disappeared in parts of Yucatán, whereas others, adopted during the colonial period, have changed their form and part of their content. Some traditions emerged from a social movement, such as the Cult of the Speaking Cross, that began with the Caste War. Even though the revolutionary impetus that guided the rebels 
in 1847 might appear dormant, nevertheless the cult of the Cruzob continues today (Burns 1996; Barabas 1996; Schele, Freidel, and Parker 1993; Sullivan 1989; Garcia de León 1989;

Bartolomé 1988; Farriss 1984; Bricker 1981; and Reed 1964).

Milpa, tradition, language, religion, and history, as presented here, are part of a dynamic system - a system in which all the elements stand in a metadialectical relationship to each other. Similarly, Mayaness is a collective expression of Maya indigenous identity: a multifaceted identity, and not a single one-like the quincunx.

\section{From Fieldwork to Quincunx/From Quincunx to Delight}

In "Altars, Crosses, and Identity", (1996b) ${ }^{15}$ Martín and Castillo Cocom propose a number of ideas that are relevant to the quincunx from the perspective of ethnographic research. One idea explored through fieldwork is that of the altars set on the sides of roads in some of the pueblos and the hinterland of Yucatán. The altars have specific meanings and functions for the people who built them, decorated them, and visit them periodically. These altars, which are generally of two distinct forms, have crosses in their centers, which vary in height from half a meter to a meter-and-a-half, or more. Of the two kinds of altars, one has a rock pile base about one meter high that has a rectangular or oval shape, with a cross of about half a meter high. The second form is an alcove-like structure, and is typically flanked by a larger cross.

Since these altars are not found everywhere in the State of Yucatán, it is significant to note that they occur in close proximity to the old maicera zone, or maize-growing zone. It could be possible that the people who live in this area have been more closely identified 
with milpa as an intrinsic part of their existence than the people who live in, say for instance, the henequen zone, where allegiance to an occupational-capitalistic based system might have had an effect of deculturation from the all-important significance of maize. At any rate, those who do keep the altars see them as a way of marking a spiritual space, or of being markers of their spiritual space.

Spirituality, in this present context, does not refer to spirituality in relation to any religion, but rather, to the expression of a collectivity: group collectivity and, odd as it may seem, individual collectivity with all its particular nuances, that an individual keeps within his own thinking. It is a somewhat Durkheimian conception of spirituality, along with that of his followers. For the purposes of this work, Durkheim's conception is not, at this point, a conflictive one. The conflict here is the question of whether or not there exists a selfdetermination oriented towards a collectivity. This is the kind of way in which nonindigenous groups somehow sense or "feel" spirituality. If there is no sense of belonging to a collectivity, and then what is more, to the one to which our fathers, and their fathers, and their fathers, belonged, then how can there be a true sense of spirituality? As bell hooks states in relation to Black women:

“...in spiritual solidarity, Black women have the potential to be a community of faith that acts collectively to transform our world." (1993:190)

I would argue that the same could be applied to the Maya. Since spirituality does not exist suspended or disconnected, it is bound to be linked to other elements, like prophecy. In the ancient Maya calendar, there is a prophesied end by cataclysm in the year 2012, the 
end of the Calendar Round. The altars, then, have also the function of protecting the people within the areas of the altars from this cataclysm. Related to this is the presence of small altars in the corners of houses, which are there possibly for the same reasons. It is safe to assume, then, that the Maya living in the maicera zone are spiritually and prophetically oriented, although the rest of the world around them may not be, or if so, in a different way. For instance, other Maya Yucatecs may share the same degree of spirituality, even when they don't raise altars or grow corn. Taken by themselves, the growing of corn or milpa, added to the content of spirituality manifest in the altars and crosses, are two important elements of a quincuncian configuration.

Since the Spanish Conquest, Maya indigenous people have adopted Christian symbols - such as the cross-as their own. The Spanish Catholic missionaries saw to it that the Maya adopted the cross as the very essence of Christianity, and that it would be a symbol of their new religion. Nevertheless, Maya indigenous people turned to Catholic symbolism only to turn it around. Thus, it is not surprising that the cross was adopted by the Maya as a symbol that marks sacred spaces and zones of protection, a purpose more than somewhat different than the original one. Today, as in the past, the modern Maya use their crosses and altars for purposes that are different altogether, albeit also representing their spirituality.

It is the contention in the paper by Martín and Castillo Cocom (1996), that a result, if not a function of, altars and crosses, is the reaffirmation of their indigenous identity. An identity that operates from the inside, or, as in the statement of Martín and Castillo Cocom, is visible only to those that live in the community, that are "in on it," so to speak. For, despite the fact that the altars and crosses are visible to anyone, their meaning, however, is only open to the community, to those who built the altars, decorate them and frequent them. 
In this sense there are two meanings or appearances to the altars and crosses. One, which could be termed etic, visible to all, just as shrines and ceremonial places for the people in the countryside, and another, its emic counterpart, which is understood and interiorized only by those Maya in the communities who hold their indigenous identity.

Nevertheless, this is only one form of present-day Maya resistance. For to a great extent, Maya behave in a "normal" and familiar way only with others that they know for sure are Maya - for instance they turn to speaking Maya in front of someone whom they suspect does not. Gaspar Pedro Gonzales, in his ethnographic novel A Maya Life tells about one Ladina woman (Doña Licha) in Jolomk'u, a Maya Community in Guatemala. Doña Licha,

"...was a lady who gave shots, prescribed medicines, cured children of the evil eye, and did favors for less money than the rest of the Ladinos. But the main thing people looked her up for was for writing letters, because she could speak their language, as long as it wasn't in front of any other Ladinos. God forbid that a Ladino should relate socially with Mayas, never. To protec herself from the 'what people say?' of the others, dona Licha took her clients to a room at the back of her house." (1995:54)

This illustrates her visibility with whom she considered her own people, and her invisibility towards those whom she didn't. It was also reflected in a special treatment towards those of her own, even if she was considered a Ladina herself, perhaps due to the fact that she also had to deal with the world of Ladinos. Maya indigenous people can switch from visibility to invisibility (Martín and Castillo Cocom 1996). Their invisibility tallies with the non-indigenous, non-Maya world, or the world of the Ladino and the $d z u l$. On the other hand, their visibility is matched with their own world, the indigenous world in the Maya communities. This would be equivalent to the alpha and gamma axes in DELIGHT quality 
of APE (All-Purpose Explanation) approach wherein

“...individuals, families, communities, species, trees-are produced as products of two variables whose dimensions are inside/outside and material/symbolic." (Fjellman 1984:108)

The visibility operates on the material/social end of the alpha axis, and on the outside end of the gamma axis, whereas the invisibility, is manifested on the symbolic/ideological end of the alpha axis, and the inside end of the gamma axis. The above comparison is intended to show that indigenous identity is dynamic, since it can move from visibility to invisibility depending on whether it is in a non-indigenous arena, or an indigenous one.

Maya indigenous identity is also contextual, depending on the attributes placed upon it from the outside. Non-Maya, whether scholars or not, have more than frequently identified Maya with a campesino ${ }^{16}$ (peasant) occupation, as well as giving them a rural setting, or a rural community. In addition to this, there is something known as "regionalism", which is very much applicable to most Yucatec people, but does not necessarily mean equivalent to Maya indigenous identity. Regionalism is part of the Yucatec folklore and pride as they are "different" from the rest of Mexico, and according to Gilbert Joseph, is:

“...the self-conscious political, cultural, and sentimental identification that has historically bound yucatecos to the state and peninsula and invariably run counter to the national process of state-building."(1991:5)

This can be observed in many aspects of Yucatecan popular culture from regional cuisine, hand-crafts, music, regional dance performed in "mestizo" attire, or at the carnival 
costume balls to a lukewarm political pseudo-stance that has been termed by outsiders as Yucatecan separatism or, as mentioned above, regionalism. Gilbert Joseph has pointed out:

"...rather than speaking of the State of Yucatan as a region, is often more meaningful to identify a metropolitan northwestern zone of commercial agriculture, centered around the capital city of Merida, and a vast, peripheral, southeastern zone of peasant production, extending into Quintana Roo and northen Belize... Thus, the concept of region is multivalent and relational, with the analytical contours of regionality often shaped by the research problem at hand." (1991:5)

It has been a sort of neo-tradition that politicians wear regional garments in order to appear before the people like one more of the group. In Mexico during the 1970s, President Luis Echeverria frequently wore guayaberas - shirts commonly worn instead of suits-thus popularizing the style in the entire country. In Mérida, Governor Dulce M. Sauri similarly wore a "hipil" at many public meetings in Yucatán and elsewhere in Mexico. Nevertheless, in neither case did the clothing have anything to do with Maya identity. Regional and indigenous identity are not the same thing: "It [wearing certain clothes] borrows the style but not the consciousness of Maya identity" (Martín and Castillo Cocom 1995). This is similar in regards to language, history, tradition, and religious practices.

Yet altars and crosses are a reality of the present that anyone can attest to. The comings and goings of other forms of identity, whether regional, national, or international, somehow do not seem to affect either the belief in altars and crosses as markers of spirituality and protection from the impending inevitable from the point of view of those Maya who uphold their identity. Whether this stance is conscious or not is beside the point. What is not, however, is that this cultural manifestation is not at all new. Even since the sixteenth century 
there is word about the relentlessness of the Maya to give up their traditions, their old idols, their old gods, their old religion (Landa 1973). It goes without saying that they have not all given up their language nor many of their traditions and customs. These too are essential components of the quincunx: traditions.

There have been many interpretations of Mayaness, all of which reflect what is perceived from an outsider perspective. It is generally the work of mostly foreign scholars who go out into the field to verify their own theoretical models through empirical data collected in an orderly ethnographical fashion-Reed, Lewis, Burns, Sullivan, Hansen, Bastarrachea, and to a smaller degree, Villa Rojas, and still others, all represent this almost inevitable tendency. Much of what they write about Maya culture is important, and well stated. It strives for objectivity. But it lacks what I think is fundamental: the "conscience of being," whether individually or collectively. bell hooks (1993:41), calls this the "acquired conscience," or "simple conscience," the conscience of an individual as if he/she were alone. When combined with spirituality it becomes the "critical conscience," which is the conscience of a collectivity. Because spirituality is also collective, the "critical conscience" finds its strength in the collectivity and helps individuals to fend off the pains of everyday hardships, something that the "simple conscience" cannot do for indigenous people who are enmeshed capitalist society. The quincunx model is about this "critical conscience", and more. Mayaness is a form of critical conscience as was shown above with relation to the possibilities of who can be considered Maya. 


\section{Conclusions}

In explaining the concept of Mayaness, or the essence of being Maya, I have established a theoretical model of Mayaness through a synthesis of various social science theories as they apply to an understanding of a Maya indigenous identity. The synthesis of these theories is based on the notion that all social phenomena are multifactorial, multifaceted and multi-vocal. Therefore, social phenomena are best explained from a variety of perspectives that broach the relevant issues from different vantage points and with diverse conceptualizations. The attempt to explain a social phenomenon, such as indigenous identity, without taking into account its multi-factorialness, greatly limits the understanding of this phenomenon. Thus rather than adopting the narrow argument of theoretical exclusivity, I have taken a broader position which asserts that causal processes operate on multiple levels simultaneously. Nevertheless, causality is but one position to take perhaps at the expense of other theoretical options. Theoretical models are both synthetic and syncretic, especially as I have employed them here incorporating useful elements of various theories to analyze existing constructs of Mayaness.

By utilizing interpretations of the Popol Vuh and the Chilam Balam texts, coupled with descriptive and ethnographic commentary, I formulated a "map" of Mayaness. The confrontation of the actual model itself with the reality of the Maya could be considered a "tour". In this work, the citations, references and ethnographies leading to the theoretical model constitute the "map". The theoretical model originating from the map was designated as a quincunx. To complement the map/quincunx, another quincunx, a theoretical metacritical one, was introduced. This allowed me to encompass theoretical models and 
orientations in related areas. I argued that Yucatec Maya identity is like a quincunx of five interconnected dimensions: history, language, milpa, religion, and tradition, each symbolically expressed as the sacred trees of life. Each of these dimensions constitutes one factor of Mayaness with none of the trees existing in isolation from the rest. The results of this study, based on text interpretation, and coupled with documentary analysis and ethnographic fieldwork, are not intended to provide a final theory that will definitively explain Maya indigenous identity. Rather this study is an attempt to examine indigenous identity, assuming a critical and analytical perspective in order to offer a model for the interpretation of Mayaness and the Yucatec Maya. Many of these interpretations reflect what is perceived from an outsider perspective. Much of what is written about Yucatec Maya culture is important and well stated with an aspiration for objectivity, but yet lacking in what I think is fundamental: "the conscience of being," whether individually or collectively. bell hooks (1993:41) calls this the "acquired conscience" or "simple conscience", the conscience of an individual as if he/she were alone. When combined with spirituality, however, it becomes the "critical conscience" which is the conscience of a collectivity. Because spirituality is also collective, then the "critical conscience" finds its strength in the collectivity and helps individuals fend off the pain of everyday hardships. I maintain that the "simple conscience" alone cannot relieve the suffering of indigenous people who are enmeshed in a capitalist society. Thus the quincunx model centers upon "critical conscience" and Mayaness then becomes a "critical conscience".

I intend this thesis to be part of what is called "el movimiento Maya" (Maya movement) which some authors (Fischer and McKenna Brown 1996:1) describe as a renaissance of Maya intellectual life; a resurgence of Maya thought. Edward Fischer and 
Robert McKenna Brown have pointed out the variety of terms that scholars and activists have used to refer to this movement: the "Maya nationalism (Smith 1991), the "pan-Mayan movement" (Fischer 1993,1996), the "Maya revitalization movement" (Wilson 1993) or the term preferred by Maya activists themselves, "el movimiento Maya."

The kaleidoscope of views concerning "el movimiento Maya," by many scholars generally considers the movement to be something new. However, "el movimiento Maya" is not new. Rather than a revitalization, contemporary Maya activism represents a "movimiento Maya" of a 505 year duration. This movement is essentially the manifestation of centuries of Maya cultural vitality and resistance, that extends as a continuous past back to the conquest. Maya activism has always been present. It is only the forms of its manifestation that have changed. Maya political activism promotes cultural and social activism and seeks political reform within the national state system. In Guatemala, the political-scholarly agenda of Maya cultural activists is based on their own conceptions of history and of the various Maya cultures within their nation. Their agenda constitutes a political and cultural contestation against the ideological and cultural globalization processes of the postmodern world. The newspaper, "El Regional", is an example of such contestation Published since 1991 it blankets Guatemala with editions in five Maya languages (Gross and Merino 1995:34). In addition Guatemalan Maya scholars have created a unified alphabet for writing Maya languages and have successfully petitioned the Guatemalan State to grant it official recognition (Fischer and McKenna 1996:15).

In Mexico, I would argue that "el movimiento Maya "manifests itself more subtly but no less effectively. In Yucatán and Chiapas there has been a re-emergence of indigenous theater (such as the Pustunich, theater; the "Sna Jtz'ibajom" and the "Fomma" groups of San 
Cristobal de las Casas, Chiapas). Another example of Mexican Maya contestation is the reclamation of archeological zones by the Chiapan and Yucatec Maya. In addition there is a continuity of oral and written Yucatec Maya tradition in Tixcacal Guardia, Quintana Roo.

There are several kinds of contributions I think that this thesis has to make. For example, a policy implication of this thesis is that it helps to create a basis for revising public education in Yucatán especially since the study of Maya culture is generally taught in Yucatán from either a macro perspective or a micro perspective. As stated earlier in this thesis, neither the macro nor the micro perspectives is by itself adequate in discussing Maya culture or Maya indigenous identity. There is a dialectic between the two sets of realities, the macro and micro, that needs to be recognized and incorporated in the Yucatecan educational system. This thesis also provides a basis for other kinds of studies concerning the Yucatec Maya, particularly on the issue of indigenous identity and its nexus with gender. For example, in the history axis of the quincunx the role of women has been neglected. If history is at the core of Mayaness, how is it that history has neglected Maya women in its analysis? The Caste War is but one example. Historical analysis of this war have simply neglected to discuss the role of women. It is assumed by most historians that the Maya warriors who were about to take Mérida in 1847 decided not to do so because the time had arrived to make milpa. The questions that arise are as follows: 1. What had Maya women been doing throughout the multi-year rebellion? 2. Who had been planting the milpa throughout the war? 3. How were Maya families fed during the conflict? 4. Should historians assume that the Caste War was only a male enterprise? I think a new analysis of the Caste War would help to de-genderize rotions of indigenous identity. 1 look forward to working on such themes in my doctoral dissertation. 


\section{Notes}

1. In general, as for instance in the Enciclopedia Yucatanense (Gobierno del Estado de Yucatán 1980 ), there is a recognition that the maize-growing zone (the Southern and Oriental geographical portions of the State)is located South of the old Merida-Puerto Juárez road that bisects the State of Yucatán. The former henequen zone used to exist as such north of this road. In an area of the easternnorthern portion of the State is the cattle-raising zone. The fishery zone is on the shores of Yucatán of the Gulf of Mexico. With regard to the Henequen zone, its denomination comes from an agave genre, henequen. From the extraction and processing of its fiber a great industry in the international markets was developed until the advent of synthetic fibers. The first henequen haciendas were formed and consolidated in the second half of the nineteenth century and they became booming capitalistic enterprises until they were nationalized towards the first half of this century. Nevertheless, henequen as a state managed industry continued until its virtual demise in the decade of the 1980s. Henequen production required large extensions of land which were growing at the expense of the land that the Maya had dedicated to the cultivation of corn (Montalvo Ortega 1988). Thus, since the middle of the nineteenth century the Yucatán Peninsula was divided into two socioeconomic regions: the henequen-zone, which surrounded the cities of Mérida and Campeche within a ratio of 80 kilometer, and the maize-zone, which includes the eastern portion of the State of Yucatán and a considerable part of the State of Quintana Roo. On this subject see: Villanueva Mukul 1993; Montalvo Ortega 1988; Paoli 1984; Joseph 1982; Robert Patch 1976; González Navarro 1970; Reed 1964; Benítez 1956; Joseph and Allen 1982).

2. Although there is a vast body of literature on the subject of colonialism and neocolonialism, it is not my purpose to discuss it here in detail. It involves the literal taking over of one culture by another; the growth of one society at the expense of another, presumably "less evolved" in a holistic sense, though mainly in the techno-economic area. Internal colonialism, then, in Mexico, is also a part of total colonialism, which manifests itself both internally and externally, in all the realms of social life. On this subject see: Burgos-Debray 1996; Field 1994; Bonfil Batalla 1994, 1992; Van Coot 1994; Zea 1993; Guzman 1992; Turner 1991; Rappaport 1990; Ouweneel 1990; Katz 1988; Bartolomé 1988; Gordon 1988; Clendinnen 1988; Hawkins 1984; Favre 1984; Wolf 1982; Garcia de León 1981; Barabas 1979; Taylor 1972; Stavenhagen 1968.

3. On social categories in contemporary Yucatán, see: Hervik 1994; Thompson 1974; Barabas 1979; Villa Rojas 1987. On social stratification before de Conquest, see: Bastarachea Manzano 1984; Roys 1943, 1957.

4. According to the renowned anthropologist, Salvador Rodríguez Losa, the term "hipil" derives from the Náhuatl word "huipil". In other areas of Mexico the term "huipil" or "güipil" is used to name the dress used by indigenous woman. In Yucatán the word used is "hipil" (Diario de Yucatán 1997c).

5. The beginning of poststructuralism can be traced back to a speech by Derrida in 1966 . He claimed that structuralism was in a transitory stage and that we were witnessing the beginning of a new age: poststructuralism (Ritzer 1992:505).

6. It was the original intention in this work to use the term "ethno-theory" to refer to the quincunx conception of the world by the Maya, that is, their cosmovision in a map and tour (following 
Castañeda 1996). However, a renowned Yucatecan Linguist, Dr. Ramón Arzápalo, suggested to me at the LASA (Latin American Studies Association), XXth International Congress, held in Guadalajara, Mexico, May 1997, that instead of using that term, which he thought was selfunderestimating, since the half "ethno" of the term belittled its importance, I should use simply, the term "theory." Because it seems to me that "theory" might seem a bit heavy, when not pretentious, or at any rate, premature, I have preferred to use "theoretical model."

7. Schele, Freidel, and Parker (1993), writing on the creation of humans stated that "....the K' iche' Popol Vu told us the world had been created, destroyed, and re-created at least three times before the present Creation, the one in which we live now" (1993:61). However, in another note of the same authors they point out the fallowing: "The Aztec counted this as the fifth creation, while the Popol Vuh counts three creations before the present, making this the fourth. We don't know the count used in the Classic period" (1993:416:note3). Thompson on the other hand writing on the Popol Vuh points out that it was in the third creation when the gods "...made the ancestors of the current race from white and yellow maize... For the K'iche' there are them, three races of created persons and two annihilations of persons in the past with a third destruction and a forth creation promised to the future"(1977:402-403). In The Books of the Chilam Balam four creations are stated (Barrera Vasquez 1972). Since there are at least three different numbers of creations steaming from various sources (three, four, and five), the position adopted in this thesis will be to adhere to the number given in the Popol Vuh and The Books of the Chilam Balam, since they seem more trustworthy than other interpretations. This position will not have any bearing on the fact that the quincunx is a five piece arrangement, for it is not the intention to transpose the number of attempts to create mankind on the quincunx arrangement, since in this arrangement the creation of mankind is already taken for granted.

8. Reading of the Popol Vuh is recommended, however, in order to get a close look at Maya cosmovision. There are several translations of the Popol Vuh into English, among which the following can be mentioned: Dennis Tedlock 1996; Edmonson 1971; Recinos, Goetz, and Morley 1950. Among the versions in Spanish are those by: Chávez 1979; Recinos 1960.

9. Among the versions in English of The Books of Chilam Balam are those by: Edmonson 1982; Craine 1979; Roys 1967; and Gordon 1913. The work of Barrera Vásquez (1963) is the most renowned Spanish version of these sacred texts.

10. "By millenarian, what is meant is a religious movement that is obsessed with salvation and the moral regeneration of society. This is a movement that viewed the world as a "dominated by an evil tyrannous power', a power that could be defeated only by a holy war sanctioned by God" (Diacon 1991:8). Millenarian movements exist wherever there have been colonial systems. The spread of these movements with a heavy content of fatalism and prophecy, that points to some heyday in the past, is worldwide. The collectivity, which is heir of a disrupted cultural system, turns to forms of survival, both materially and as members of indigenous groups. Indigenous peoples, in this case the Maya, employed their cosmology and religious practice to organize, to create political strategy, and to promote revolution. Two examples of millenarian are the Jacinto Canek's uprising in 1761, and the Caste War 1847-1902. On millenarian movements among the Maya, see: Reed 1964; Sullivan 1989; Katz 1990; Bricker 1981; Farris 1984; González Navarro 1970. On millenarian movements around the world see: Hue-Tam 1983; Naquin 1976; Clemena 1979; Hobsbawn 1963.

11. Gaspar Pedro González belongs to the Q'anjob'al Maya of Guatemala. He is the author of the first novel written from the indigenous perspective: A Mayan Life (1995). 
12. The Spanish colonial period in Guatemala and Mexico begins in the sixteenth century and concludes in the nineteenth century. During this period, both countries were Capitanias Generales - each was an independent colonial unit linked to Spain, not to each other-one was called The Real Audiencia de la Capitania General de Guatemala and the other was the Capitanía General de la Nueva España, respectively. Both countries got their independence from Spain at the same time (1824). For a better understanding of this period, with regard to the Maya, the reading of Nancy Farris' Maya Society under Colonial Rule: The Collective Enterprise of Survival (1984) is recommended. See also: Bonfil Batalla 1994; Guzman 1992; Zea 1991; González y González 1989; Clendinnen 1988; Garcia de León 1981; Patch 1976; and Taylor 1992.

13. Other texts produced by the Quiché Maya group, besides the Popol Vuh, are the Annals of Kaqchikel and the play Rabinal Achi. Among the legacy of texts by the Yucatec Maya are The Books of Chilam Balam, the Ritual of the Bakabs, the Cantares of Dzitbalche and the Perez Codex. Besides these colonial texts, three Codices that survived from the Spanish holocaust: the Dresden, Paris, and Madrid Codices.

14. According to Gaspar Pedro González, "The Heart of the Sky and Heart of the Earth, in a metaphoric language, is the conception of a macro living being, a sort of great thought and an almighty intelligence... in the Book of Council, The Popol Vuh of the Maya, a triple identity of the Heart of the Sky and the Heart of the Earth is mentioned, conforming one sole divine nature: "The first one is called Caculha Huracan... The second is Chipi of the Scathe third is Raxa Caculha"" (1997:2-3). In a note, the author clarifies that the three deities are the Heart of the Sky and Heart of the Earth. However, "It is a phrase that seems devoid of all logic because plural and singular are conjugated, but it is due to the concept itself." Other names for The Heart of The Sky and the Heart of the Earth in different Maya languages are: The Maker and Modeler; Mother-Father; Tepeu and Gugumatz; Alom and Kajolom; Hunab Ku (the Only Deity); World God and Ajau which means the same as owner; Tz'aqol and B'itol (1997:3). On this subject see also: Schele, Freidel, and Parker 1993; Breton 1994; MacLeod 1992; Villa Rojas 1987; Sosa 1988; Brito 1979; Landa 1973; Barrera Vasquez 1972; Thompson 1970; Huxley 1965; Morley 1983.

15. Although the title of our paper in the AAA program in 1996 was "Political Representations among the Yucates Maya", our paper actually focused more upon indigenous identity and is referred to as "Altars, Crosses and Identity." We made this thematic change to reflect more accurately the results of our most recent fieldwork, undertaken in the summer of 1995.

16. Re Cruz define the term peasant as: "...those who live in or near the village and participate in the traditional, agrarian economy of the rural community, and those who, although residing and working in the city, still have an active role in the local village affairs." (1996:35) 


\section{REFERENCES}

Aguirre Beltrán, Gonzálo. 1992. Obra Antropológica XI: Obra Polémica. México: Fondo de Cultura Económica.

Barabas, Alicia. 1996. "La Rebelión Zapatista y el Movimiento Indio en México" Brasil: Departamento de Antropologia Universidade de Brasilia. Serie Antropologia No. 208.

. 1979. "Colonialismo y Racismo en Yucatán: Una Aproximación Histórica y Contemporánea". En: Revista Mexicana de Ciencias Políticas y Sociales. México: UNAM. No.97:105-140.

Barrera Rubio, Alfredo. 1984. El Modo de Producción Tributario en Mesoamérica. Escuela de Ciencias Antropológicas, Mérida, Yucatán, México: Ediciones de la Universidad de Yucatán.

1984. "Consideraciones sobre el Modo de Producción Asiático entre los Mayas" En: El Modo de Producción Tributario en Mesoamérica. Escuela de Ciencias Antropológicas, Mérida, Yucatán, México: Ediciones de la Universidad de Yucatán.

Barrera Vásquez, Alfredo y Silvia Rendón. 1972. El Libro de los Libros de Chilam Balam. México: Fondo de Cultura Económica.

Barret, Richard A. 1991. Culture and Conduct: An Excursion in Anthropology. Belmont, California: Wadsworth Publishing Company.

Bartolomé, Miguel Alberto. 1996a. "Pluralismo Cultural y Redefinición del Estado en México". Brasil: Departamento de Antropologia Universidade de Brasilia. Serie Antropologia No. 210.

. 1996b. "Movimientos Etnopolíticos y Autonomías Indígenas en México". Brasil: Departamento de Antropologia Universidade de Brasilia. Antropologia No. 209.

1988. La Dinámica Social de los Mayas de Yucatán: Pasado y Presente de la Situación Colonial. México: Instituto Nacional Indigenista.

Bartra, Roger, ed. 1974. El Modo de Producción Asiático. México: Editorial Era.

Bastarrachea Manzano, Juan Ramón. 1978. "El Sistema de Parentesco entre los Mayas Peninsulares del Siglo XVI". En: Memorias de la Primera Semana de la Historia de Yucatán. Tomo I. Mérida, Yucatán, México: Ediciones de la Universidad de Yucatán. 
Behar, Ruth, and Deborah Gordon, ed. 1995. Women Writing Culture. Berkeley: University of California Press.

Benítez, Fernando. 1956. Ki: El Drama de un Pueblo y una Planta. México: Fondo de Cultura Económica.

Bojórquez Urzáiz, Carlos. 1984. "Introducción a la Agricultura Maya Yucatanence: un Intento Historiográfico". En: El Modo de Producción Tributario en Mesoamérica. Escuela de Ciencias Antropológicas, Mérida, Yucatán, México: Ediciones de la Universidad de Yucatán.

Bonfil Batalla, Guillermo. 1994. México Profundo: Una Civilización Negada. México: Editorial Grijalvo.

— 1992. Pensar en Nuestra Cultura. México: Alianza Editorial.

Brannon, Jeffery, and Gilbert M. Joseph. 1991. Land, Labor, and Capital in Modern Yucatan. Tuscaloosa: The University of Alabama Press.

Breton, Alain, ed. 1994. Los Mayas. México: Editorial Grijalvo.

Bricker, Victoria R. 1981. The Indian King: The Indian Christ. Austin: University of Texas Press.

Brito Sansores, William. 1979. "Los Libros de Chilam Balam". En: Enciclopedia Yucatanence. Tomo X. Mérida, Yucatán, México: Edición Oficial del Gobierno de Yucatán.

Burgos-Debray, Elisabeth. 1996. I Rigoberta Menchú an Indian Woman in Guatemala. London: Verso.

Burns, Allan F. 1996. "Siempre Maya: Identidad Cultural en el Mundo Yucateco de Ciudades y Turistas". En: Revista de la Universidad Autónoma de Yucatán. Mérida, Yucatán, México: Ediciones de la Universidad Autónoma de Yucatán 11:197:29-37.

1983. An Epoch of Miracles: Oral Literature of the Yucatec Maya. Austin: University of Texas Press.

Cardiel Coronel, Cuauhtémoc. 1989. “Cancún: Turismo, Subdesarrollo Social y Expansión Sectario Religiosa”. En: Religión y Sociedad en el Sureste de México. México D.F.: Cuadernos de la Casa Chata No. 166. CIESAS del SURESTE. Centro de Investigaciones y Estudios Superiores en Antropología Social.

Castañeda, Quetzil. 1996. In the Museum of Maya Culture: Touring Chichen Itza. Minneapolis: University of Minnesota Press. 
Clemena Ileto, Reynaldo. 1979. Pasyon and Revolution: Popular Movements in the Philippines, 1840-1910. Quezon City, Manila: Ateneo de Manila University Press.

Clendinnen, Inga. 1988. Ambivalent Conquests: Maya and Spaniards in Yucatan, 1517-1570. Cambridge: Cambridge University Press.

Cojtí Cuxil, Demetrio. 1991. Configuración del Pensamiento Político del Pueblo Maya. Asociación de Escritores Mayances de Guatemala. Quetzaltenango, Guatemala: Talleres "El Estudiante".

Craine, Eugene R., and Reginald C. Reindorp. 1979. The Codex Pérez and the Books of Chilam Balam of Mani. Norman: University of Oklahoma Press.

Chávez, Adrián. 1979. Pop Wuj. México: Ediciones de la Casa Chata.

Dahlgren de Jordán, Barbro. 1987. Historia de la Religión en Mesoamérica y Areas Afines, I Coloquio. México: Universidad Nacional Autónoma de México.

de Certeau, Michel. 1984. The Practice of Everyday Life. Minneapolis: University of Minnesota Press.

Derrida, Jacques. 1976. Of Grammatology. Baltimore: John Hopkins University Press.

Diacon, Todd A. 1991. Millenarian Vision, Capitalist Reality: Brazil's Contestado Rebellion, 1912-1916. Duke University Press.

Diario de Yucatán. 1997a. "La Pobreza y la Invasión de Modas de Fuera Generaron Drástico Cambio Entre los Mayas". Página Internet del Diario de Yucatán. 20 de Octubre. 1997b. "Marcha Zapatista en las Ruinas Mayas de Cobá: Exigen la Devolución de las Zonas Arqueológicas”. Página Internet del Diario de Yucatán. 20 de Octubre. 1997c. “Sin Errores', los Nuevos Libros de Historia y Geografia”. Página Internet del Diario de Yucatán. 4 Agosto.

1997d. "El Mosáico Etnico del Mundo Maya". Página Internet del Diario de Yucatán. 15 Mayo.

Edmonson, Munro. 1982. The Ancient Future of the Itza: The Book of Chilam Balam of Tizimin. Austin: University of Texas Press.

1971. The Book of Counsel: The Popol Vuh of the Quiché Maya of Guatemala. Middle American Research Institute, Pub. 35. New Orleans: Tulane University. 
Farriss, Nancy M. 1984. Maya Society under Colonial Rule: The Collective Enterprise of Survival. Princeton :Princeton U. Press.

Favre, Henri. 1984. Cambio y Continuidad entre los Mayas de México: Contribución al Estudio de la Situación Colonial en America Latina. México: Instituto Nacional Indigenista.

Fischer, Edward and Robert McKenna Brown. 1996. Maya Cultural Activism in Guatemala. Austin: University Of Texas Press.

Field, Les W. 1994. "Who are the Indians? Reconceptualizing Indigenous Identity, Resistance and the Role of Social Science in Latin America." LARR 29:3:237-248.

Fjellman, Stephen M. 1984. "What Ramanujan Didn't Say: Sociology and the Discourse of Order.” In: Current Perspectives in Social Theory. Vol.5:101-119.

Frye, David. 1996. Indians into Mexicans: History and Identity in a Mexican Town. Austin: University of Texas Press.

Gamio, Manuel. 1992. Forjando Patria. México: Editorial Porrúa.

Garcia de León, Antonio. 1981. Resistencia y Utopia: Memorial de Agravios y Crónicas de Revueltas y Profecías Acaecidas en la Provincia de Chiapas Durante los Ultimos 500 años de su Historia. Tomo I y II. México: Era.

Geertz, J. Clifford. 1991. "Géneros Confusos: La Refiguración del Pensamiento Social". En: Carlos Reynoso: El Surgimiento de la Antropología Postmodernista. México: Editorial Gedisa, 63-77.

1973. The Interpretation of Cultures. New York: Basic Books, Inc., Publishers.

Godelier, Maurice. 1980. Formaciones Precapitalistas. México: Editorial Quinto Sol.

- 1972. Sobre el Modo de Producción Asiático. Barcelona, España: Editorial Martínez Rosa.

Golde P., ed. 1970. Woman in the Field. Chicago: Aldine.

González, Gaspar Pedro. 1997. “Corazón del Cielo, Corazón de la Tierra: Conceptos del Universo entre los Mayas Actuales”. Paper presented at LASA, Guadalajara México.

1995. A Maya Life. Rancho Palos Verdes, California: Yax te' Press.

González y González, Luis. 1989. Todo es Historia. México: Cal y Arena. 
González Navarro, Moisés. 1970. Raza y Tierra: La Guerra de Castas y el Henequen. México: El Colegio de México.

Gordon, George B. 1913. The Book of Chilam Balam of Chumayel. Philadelphia: The University Museum of Philadelphia.

Gross, Liza \& Merino Ruth. 1995. "Las seis lenguas de El Regional" En: Pulso del Periodismo. Mexico: Jul-Sep. 25:34-36.

Guzmán, Carlos. 1992. "Guatemala: Una Interpretación Histórico Social". En: Gonzálo Beltrán Aguirre. Obra Antropológica. XI Obra Polémica. México: Fondo de Cultura Económica.

Harris, Marvin. 1997. Culture, People, Nature: An Introduction to General Anthropology. NY: Addison Longman, Inc.

- 1968. The Rise of Anthropological Theory. New York: Thomas Y. Crowell.

Hawkins, John. 1984. Inverse Images: The Meaning of Culture, Ethnicity, and Family in Postcolonial Guatemala. Albuquerque: University of New Mexico Press.

Hervik, Peter. 1994. Social Categories in Yucatan. Durhan: Duke-UNC Program in Latin American Studies.

Hobsbawn, E. J. 1963. Primitive Rebels: Studies in Archaic Forms of Social of Social Movement in the $19^{\text {th }}$ and $20^{\text {th }}$ Centuries. Manchester University Press.

hooks, bell. 1993. Sisters of the Yam: Black Women and Self-Recovery. Boston, MA: South End Press.

Hue-Tam, Ho Tai. 1983. Millenarianism and Peasant Politics in Vietnam. Harvard University Press.

Huxley, Aldoux. 1965. Prácticas Religiosas en Mesoamérica. Guatemala: Editorial, José de Pineda.

Iglesias Ponce de León, Josefa, y Francesc Ligorred Perramón. 1993. Perspectivas Antropológicas en el Mundo Maya. Madrid: Sociedad Española de Estudios Mayas.

Joseph, Gilbert M., and Allen Wells. 1982. "Corporate Control of a Monocrop Economy." In: Latin America Research Review. 17:69-79.

Joseph, Gilbert M. 1991. “The New Regional Historiography at Mexico's Periphery." In: Jeffery T. Brannon and Gilbert M. Joseph. Land, Labor, and Capital in Modern Yucatan. Tuscaloosa: The University of Alabama Press. 
1982. Revolution from Without: Yucatan, Mexico, and the United States, 18801924. Cambridge: Cambridge University Press.

Katz, Friedich. 1988. Revuelta, Rebelión y Revolución: La Lucha Rural en México del Siglo XVI al Siglo XX. México: Ediciones Era.

Kikumara, Akemi. 1981. Through Harsh Winters: The Life of a Japanese Immigrant Woman. Novato, California: Chandler \& Sharp Publishers, Inc.

Landa, Fray Diego de. 1973. Relación de las Cosas de Yucatán: 1560. México: Editorial Porrúa.

Lévi-Strauss, Claude . 1949. Les Structures Elementaires de la Parente. Paris: Presses Universitaires de France.

Ligorred Perramón, Francesc. 1993. "Cuestiones de Habla, de Lengua y de Literatura Mayas (Estudios y Propuestas)”. En: Josefa Iglesias Ponce de León y Francesc Ligorred, Perspectivas Antropológicas en el Mundo Maya. Madrid: Sociedad Española de Estudios Mayas.

Logan, Kathleen. 1995. "Women's Participation in Democratic Transformation: Yucatan." In: Annals of the Southeast Council on Latin American Studies. Vol. 26:77-89.

MacLeod, Barbara. 1992. "Maker, Modeler, Bearer, Begetter: The Paddlers as Chan Itz'at." In: Workshop at Texas for the XVIth Maya Hieroglyphic Workshop at Texas, with commentaries on the Group of the Cross at Palenque. Austin: Art Department, University of Texas. 257-259.

Martín, Kathleen and Juan Castillo Cocom. 1997. "Los Mayas en el Contexto de la Política Regional”. Paper presented at the Latin American Studies Association. Guadalajara, México.

- 1996a. "A Still Unfinished Conversation: "Our" Maya-North American Collaboration." Paper presented at Southeast Council on Latin American Studies (SECOLAS). Miami, Florida.

- 1996b. "Political Representations of the Yucatec Maya." Paper presented at the American Anthropological Association. San Francisco, California.

- 1995. "Indigenous Participation in the State." Paper presented at the American Anthropological Association. Washington D.C.

Marx, Karl. 1964. Pre-capitalist Economic Formations. Eric J. Hobsbawn (ed.). New York: International Publishers. 
Massey, Douglas, and Joaquin Arango. 1993. "Theories of International Migration: A Review and Appraisal." In: Population and Development Review. 19(3); 431-466.

Merton, R. K. 1972. "Insiders and Outsiders: A Chapter in the Sociology of Knowledge." American Journal of Sociology. 78(1)(July): 9-47.

Montalvo Ortega, Enrique. 1988. "Revueltas y Movilizaciones Campesinas en Yucatán: Indios, Peones y Campesinos de la Guerra de Castas a la Revolución". En: Friedich Katz (Compilador), Revuelta, Rebelión y Revolución: La Lucha Rural en México del Siglo XVI al Siglo XX. México: Ediciones Era.

Montoliu Villar, María. 1987. "Conceptos Sobre la Forma de los Cielos entre los Mayas". En: Barbro Dahlgren de Jordán, Historia de la Religión en Mesoamérica y Areas Afines: I Coloquio. México: Universidad Nacional Autónoma de México.

Morley, Sylvanus Griswold. 1981. "La Agricultura”. En: Luis Várguez Pasos, La Milpa entre los Mayas de Yucatán. Mérida, Yucatán, México: Ediciones de la Universidad de Yucatán.

1983. The Ancient Maya. Stanford: Stanford University Press.

Moseley, Edward, and E. Terry. 1980. Yucatan: A World Apart. Tuscaloosa: University of Alabama Press.

Naquin, Susan. 1976. Millenarian Rebellion in China: The Eight Trigrams Uprising of 1813. Yale University Press.

Nash D. 1963. "The Ethnologist as Stranger: An Essay in the Sociology of Knowledge." Southeastern Journal of Anthropology. 19:149-167.

Ouweneel, Arij. 1990. "Altepeme and Pueblos de Indios: Some Comparative Perspectives on the Analysis of the Colonial Indian Communities." In: Arij Ouweneel and Simon Miller, ed. The Indian Community of Colonial Mexico. Amsterdam: CEDDLA, Latin American Series No. 58. pp. 1-37.

Patch, Robert. 1976. "La Formación de las Estancias y las Haciendas en Yucatán durante la Colonia". En: Revista de la Universidad de Yucatán. Mérida, Yucatán, México: Ediciones de la Universidad de Yucatán. XVII: No. 106. Julio-Agosto.

Paoli, Francisco José. 1984. Yucatán y los Origenes del Nuevo Estado Mexicano. México: Editorial Era.

Rappaport, Joanne. 1990. The Politics of Memory: Native Historical Interpretation in the Colombian Andes. Cambridge: Cambridge University Press. 
Re Cruz, Alicia. 1996. The Two Milpas of Chan Kom: A Study of Socioeconomic and Political Transformations in a Maya Community. Albany, New York: State University of New York Press.

Recinos, Adrián. 1960. Popol Vuh: Las Antiguas Historias del Quiché. México: Fondo de Cultura Económica.

Recinos, Adrián, Delia Goetz, and Sylvanus G. Morley. 1950. Popol Vuh: The Sacred Book of the Quiché Maya of Guatemala. Norman: University of Oklahoma Press.

Redfield, Robert. 1941. The Folk Culture of Yucatan. Chicago: University of Chicago Press.

Reed, Nelson. 1964. The Cast War of Yucatan. Stanford: Stanford University Press.

Reynoso, Carlos, ed. 1991. El Surgimiento de la Antropología Postmodernista. México: Editorial Gedisa.

Roys, Ralph L. 1967. The Book of the Chilam Balam of Chumayel. Norman: University of Oklahoma Press.

- 1957. The Political Geography of the Yucatan Maya. Washington: Carnegie Institution of Washington.

- 1943. The Indian Background of Colonial Yucatan. Washington: Carnegie Institution of Washington.

Sam Colop, Enrique. 1996. "The Discourse of Concealment and 1992." In: Fischer, Edward, and Robert McKenna Brown, Maya Cultural Activism in Guatemala. Austin: University of Texas Press.

Schele Linda, David Freidel, and Joy Parker. 1993. Maya Cosmos: Three Thousand Years on the Shaman's Path. New York: William Morrow and Company, Inc.

Sosa, John. 1988. "The Maya Sky, the Maya World: A Symbolic Analysis of Yucatec Maya Cosmology. Ph.D. dissertation. Albany: State University of New York at Albany.

Sperber, Dan. 1991. "Etnografía Interpretativa y Antropología Teórica". En: Antropología y Epistemología. México: Revista de la Universidad Autónoma Metropolitana. 1:1

Stavenhagen, Rodolfo. 1968. "Classes, Colonialism, and Acculturation. ”In: Joseph Kahl, Comparative Perspectives on Stratification: México, Great Britain, Japan. Boston: Little, Brown, and Company, 31-63.

Sullivan, Paul. 1991. Conversaciones Inconclusas: Mayas y Extranjeros entre dos Guerras. México: Editorial Gedisa. 
-1989. Unfinished Conversations: Mayas and Foreigners Between Two Wars. New York: Alfred A. Knopf.

Tedlock, Dennis. 1996. Popol Vuh: The Definitive Edition of the Mayan Book of the Dawn of Life and the Glories of God and Kings. New York: Simon and Schuster.

- 1991. "Preguntas Concernientes a la Antropología Dialógica". En: Reynoso, Carlos, ed. El Surgimiento de la Antropología Postmodernista. México: Editorial Gedisa, 1991: 275-288.

Taylor, William. 1972. Landlord and Peasant in Colonial Oaxaca. Stanford: Stanford University Press.

Thompson, J. Eric. 1970. Maya History and Religion. Norman: University of Oklahoma Press.

Thompson, Richard. 1974. "Aires de Progreso: Cambio Social en un Pueblo Maya de Yucatán”. Mexico: Serie Antropológica No. 30. SEP-INI.

Tong, Rosemarie. 1989. Feminist Thought: A Comprehensive Introduction. San Francisco: Westview Press.

Turner, Terence. 1991. "Representing, Resisting, Rethinking: Historical Transformations of Kayapo Culture and Anthropological Consciousness." In: George W. Stocking, Colonial Situations: Essays on the Contextualization of Ethnographic Knowledge. Madison: University of Wisconsin Press. pp. 285-313.

Van Coot, Donna Lee. 1994. Indigenous Peoples and Democracy in Latin America. New York: St. Martin's Press.

Várguez Pasos, Luis, ed. 1981. La Milpa entre los Mayas de Yucatán. Mérida, Yucatán, México: Ediciones de la Universidad de Yucatán. 1981. “La Milpa y los Milperos del 'Oriente’ de Yucatán”. En: Luis Várguez Pasos, La Milpa entre los Mayas de Yucatán. Mérida, Yucatán, México: Ediciones de la Universidad de Yucatán.

Villanueva Mukul, Eric. 1993. Crisis Henequenera, Reconversión Económica y Movimientos Campesinos en Yucatán: 1983-1992. Mérida, Yucatán, México: Maldonado Editores/Facultad de Ciencias Antropológicas de la Ediciones de la Universidad Autónoma de Yucatán.

Villa Rojas, Alfonso. 1987. Los Elegidos de Dios: Etnografia de los Mayas de Quintana Roo. México: Instituto Nacional Indigenista. 
- 1945. The Maya of East Central Quintana Roo. Washington: Carnegie Institution of Washington.

Vogt, Evon Z. 1990. The Zinacantecos of Mexico: A Modern Maya Way of Life. Harvard University: Harcourt Brace Jovanovich College Publishers.

Vogt, Evon Z 1970. The Zinacantecos of Mexico: A Modern Maya Way of Life. New York: Holt, Rinehart and Winston, Inc.

Watanabe, John M. 1997. Maya Saints and Souls in a Changing World. Austin: University of California Press.

Weber, Max. 1976. The Protestant Ethic and the Spirit of Capitalism. New York: Charles Scribner's Sons.

White, Leslie. 1949. The Science of Culture: The Study of Man and Civilization. New York: Farrar, Strauss.

Wolf, Eric R. 1982. Europe and the People Without History. Berkeley: University of California Press.

Zea, Leopoldo. 1991. Quinientos Años de Historia, Sentido y Proyección. México: Fondo de Cultura Económica. 